\title{
Clay Mineral Cycles Identified by Diffuse Spectral Reflectance in Quaternary Sediments From the Northwind Ridge: Implications for Glacial- Interglacial Sedimentation Patterns in the Arctic Ocean
}

Lyanne N. Yurco

Joseph D. Ortiz

Leonid Polyak

Dennis A. Darby

Old Dominion University

Kevin A. Crawford

Follow this and additional works at: https://digitalcommons.odu.edu/oeas_fac_pubs

Part of the Environmental Sciences Commons, Geology Commons, and the Oceanography Commons

\section{Repository Citation}

Yurco, Lyanne N.; Ortiz, Joseph D.; Polyak, Leonid; Darby, Dennis A.; and Crawford, Kevin A., "Clay Mineral Cycles Identified by Diffuse Spectral Reflectance in Quaternary Sediments From the Northwind Ridge: Implications for Glacial-Interglacial Sedimentation Patterns in the Arctic Ocean" (2010). OEAS Faculty Publications. 31.

https://digitalcommons.odu.edu/oeas_fac_pubs/31

\section{Original Publication Citation}

Yurco, L.N., Ortiz, J.D., Polyak, L., Darby, D.A., \& Crawford, K.A. (2010). Clay mineral cycles identified by diffuse spectral reflectance in Quaternary sediments from the Northwind Ridge: Implications for glacial-interglacial sedimentation patterns in the Arctic Ocean.

Polar Research, 29(2), 176-197. doi: 10.1111/j.1751-8369.2010.00160.x 


\title{
Clay mineral cycles identified by diffuse spectral reflectance in Quaternary sediments from the Northwind Ridge: implications for glacial-interglacial sedimentation patterns in the Arctic Ocean
}

\author{
Lyanne N. Yurco, ${ }^{1}$ Joseph D. Ortiz, ${ }^{2}$ Leonid Polyak, ${ }^{3}$ Dennis A. Darby ${ }^{4}$ \& Kevin A. Crawford ${ }^{3}$ \\ 1 Rosenstiel School of Marine and Atmospheric Science, University of Miami, Miami, FL 33149, USA \\ 2 Department of Geology, Kent State University, Kent, $\mathrm{OH} 44242$, USA \\ 3 Byrd Polar Research Center, Ohio State University, Columbus, OH 43210, USA \\ 4 Old Dominion University, Norfolk, VA 23529, USA
}

\section{Keywords}

Arctic Ocean Quaternary palaeoclimate; Arctic Oscillation; clay mineral provenance; glacial-interglacial cycles; diffuse spectral reflectance; R-mode factor analysis.

\section{Correspondence}

Lyanne N. Yurco, Rosenstiel School of Marine and Atmospheric Science, University of Miami, Miami, FL 33149, USA. E-mail: lyurco@rsmas.miami.edu

doi:10.1111/j.1751-8369.2010.00160.x

\begin{abstract}
A Quaternary record of fine-grained sediment composition is used to investigate Arctic Ocean climate variability on glacial-interglacial time scales. Diffuse spectral reflectance data from sediment core P1-92AR-P25 from the Northwind Ridge, north of Alaska, demonstrates cyclic variations in mineralogy. Varimaxrotated R-mode factor analysis of down-core data revealed three major mineralogical assemblages, which were then compared with the content of manganese, a proxy for basin ventilation, and thus glacial-interglacial cycles. Results indicate that factor 1 , a smectite + chlorite clay assemblage, was delivered to the core site during interglacials, either by fluvial discharge or sea-ice drift from Siberian rivers or inflow from the Bering Sea. Factor 2, an illite + goethite assemblage, is related to glacial periods, and was probably transported from the Laurentide Ice Sheet by icebergs or meltwater. Factor 3, glauconite, might have been sourced from the North Slope region of Alaska during deglacial intervals, or from dolomites associated with Laurentide iceberg-discharge pulses. The observed variations in sediment source and transport mechanisms arise from glacial-interglacial changes in sea level, the size of the terrestrial ice sheets surrounding the Arctic Ocean, the extent of sea-ice cover and altered atmospheric circulation. The reconstructed glacialinterglacial circulation patterns from the Late Quaternary show some similarity with modern circulation changes presumably related to the monthly- to decadally-fluctuating Arctic Oscillation. However, because the Arctic Oscillation operates on much shorter time scales, further research is necessary to better understand the driving mechanism for the changes observed over glacialinterglacial cycles, and the potential role of ocean-atmospheric interaction.
\end{abstract}

Focus on the Arctic has increased in recent years in an attempt to better understand climate change. A major reason for this is the region's climatic sensitivity, which enables us to see dramatic changes on annual to decadal time scales. For example, September 2007 marked a new minimum in sea-ice extent as a result of a warming climate and changing atmospheric conditions (Comiso et al. 2008). Not only is the Arctic sensitive to climate change, but it has the ability to amplify changes globally. The melting of ice contributes to a positive albedo feedback, augmenting the warming process and fuelling more melting. Also, the addition of freshwater from melting ice can alter North Atlantic Deep Water formation, affecting global ocean circulation and, consequently, the Earth's climate (Holland et al. 2001; Curry \& Mauritzen 2005). Arctic Ocean sediment provides palaeoceanographic evidence of past climatic conditions that may help us better understand the changing Arctic climate system, which remains poorly understood. 
Sedimentation in the Arctic Ocean is affected by glacial cycles, sea-ice coverage, ocean circulation and atmospheric conditions, and thus provides a record of their combined effect. Changes in sea-ice extent can affect the amount and type of sedimentation, sea level and glaciations influence source regions and delivery mechanisms, and circulation directly impacts transportation pathways. These interrelated variables are also tied to atmospheric conditions. For example, the Arctic Oscillation (AO), as discussed below, has been shown to modulate sea-ice circulation, extent and thickness on seasonal-decadal, and perhaps longer, time scales (Kwok 2000; Polyakov \& Johnson 2000; Rigor et al. 2002; Polyakov et al. 2003; Serreze et al. 2003; Zhang et al. 2003; Darby \& Bischof 2004). Studying the interaction of these climatic processes and their variability over glacial-interglacial time scales can provide us with a better understanding of the long-term natural changes in the Arctic.

Seeking to use the sedimentary record to unravel Arctic climate conditions, and their cyclic variations during glacial-interglacial periods of the Late Pleistocene, this study examines a sediment core from the Northwind Ridge in the Amerasian Basin, about $300 \mathrm{~km}$ north of Alaska. We present a record of cyclic clay mineral variations that correspond to cold, glacial conditions and warm, interglacial conditions. Clay minerals in the Arctic have been used as provenance indicators, as they tend to occur in geographically distinct regions (Clark et al. 1980; Naidu \& Mowatt 1983; Dalrymple \& Maass 1987; Darby et al. 1989; Petschick et al. 1996; Vogt 1997; Winter et al. 1997; Wahsner et al. 1999; Kalinenko 2001; ViscosiShirley, Mammone et al. 2003; Viscosi-Shirley, Pisias et al. 2003; Stein et al. 2004; Stein 2008). By comparing clay mineral assemblages with a glacial-interglacial climate record, we can interpret potential transport mechanisms and pathways, and thus piece together an understanding of the dynamic climate processes that contributed to the sediment record.

\section{Geologic and oceanographic setting}

Core P1-92AR-P25, hereafter referred to as P25, was collected by the US Geological Survey from the east slope of the Northwind Ridge (eastern ridge of the Chukchi Borderland) from a water depth of $1625 \mathrm{~m}$ (Fig. 1) (Arctic Summer West Scientific Party 1993). Because of its proximity to sediment sources and the sea-ice margin, resulting in elevated sedimentation rates on the southern Northwind Ridge, this site provides a more expanded and better resolved palaeoclimatic section in comparison with many sites from the interior of the Arctic Ocean (Polyak et al. 2009). The transport of sediment in the Arctic Ocean (except for turbidites) is mostly influenced by the surface circulation of sea ice and icebergs (Clark et al. 1980; Bischof \& Darby 1997; Phillips \& Grantz 2001), but fine-grained silts and clays can also be transported or redeposited by currents in intermediate or deep waters (Hunkins et al. 1969; Winkler et al. 2002).

In the Arctic Ocean today, there are two major surface current systems: the Trans-Polar Drift (TPD) that moves from the Siberian shelf towards the Fram Strait, across the Eurasian Basin, and the Beaufort Gyre (BG), a clockwiserotating current system that dominates the circulation in the Amerasian Basin (Colony \& Thorndike 1984) (Fig. 1). Besides the effect of the TPD and BG surface currents, the P25 core site may be influenced by the northflowing current through the Bering Strait that flows across the Chukchi Sea west of the Chukchi Borderland (Weingartner et al. 2005). This current turns east, and is incorporated into an eastward flow formed by brine rejection during freeze-up, that forms part of the Beaufort Undercurrent (BU) at depths below about $50 \mathrm{~m}$ to perhaps 2500 m (Aagaard 1984; Weingartner et al. 2005; Woodgate et al. 2005). Whether the BU actually flows along the Northwind Scarp, where P25 is located, is uncertain.

High-density plumes formed by brine rejection along with comparably infrequent turbidity flows are thought to be the primary origin of deep water in the Canada Basin. It is the warmest and saltiest deep water in the Arctic Ocean (Campbell \& Clark 1977; Aagaard et al. 1985), and because salinity also increases with depth in the basin, the high salinity waters cannot originate from adjacent basins or the upper water column. Instead, they must be derived from the continental shelf, where salt rejection during freezing creates dense brines, which mix with colder water from below to form deep water plumes (Aagaard et al. 1985). These brine rejection density flows can carry sediments to great depths, and may provide a means of their transport to the P25 site.

In addition, intermediate currents can affect sedimentation. Warm water from the Atlantic, originating in the Norwegian Current, enters the Arctic Ocean via two branches: the Fram Strait branch (the West Spitsbergen Current) and the Barents Sea branch. These branches cool and sink to intermediate depths, meeting north of the Kara Sea, and flowing cyclonically throughout the deep basins as narrow boundary currents along the continental slopes and ridges. However, only the Barents Sea branch reaches the southern Canada Basin (and the Northwind Ridge) beyond the Chukchi Cap (Rudels et al. 1994; Rudels et al. 2004) (Fig. 1).

\section{Methods}

Diffuse spectral reflectance (DSR) measurements were made on the surface of the entire P25 core using a 


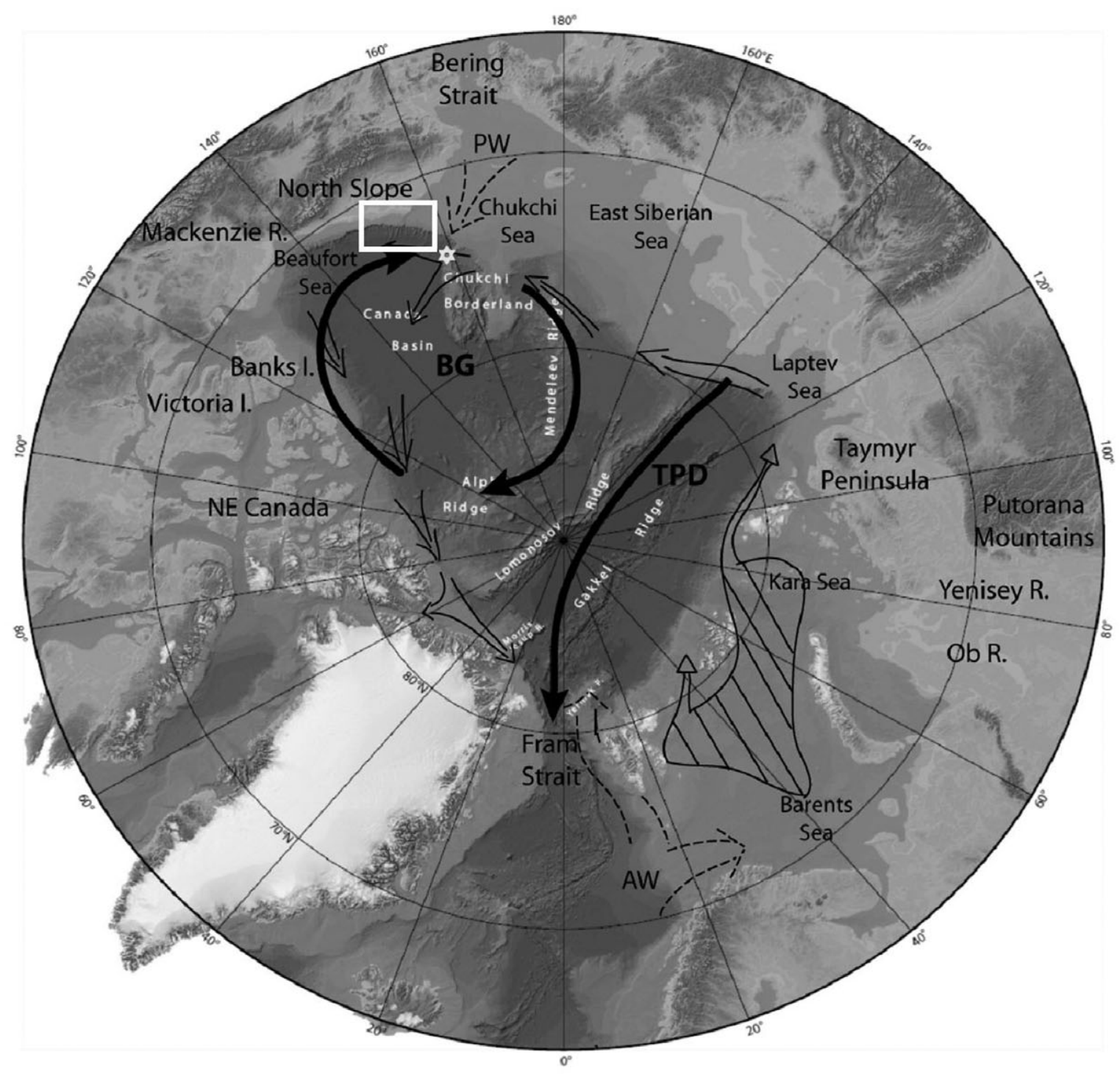

Bathymetric and topographic tints

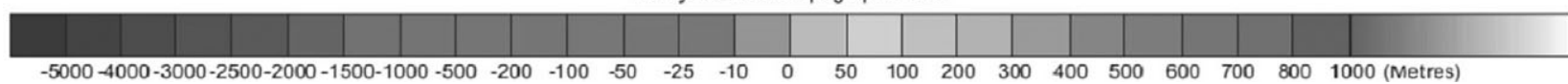

Fig. 1 The International Bathymetric Chart of the Arctic Ocean (IBCAO) with modern surface circulation patterns, the Transpolar Drift (TPD) and Beaufort Gyre (BG), indicated by thick black lines. The white star indicates the location of core P25 on the Northwind Ridge in the Chukchi Borderland. Intermediate waters that reach the southern Canada Basin (from Rudels et al. 2004) are shown as follows: dashed arrows indicate inflow of Atlantic Water (AW) and Pacific Water (PW); black diagonals indicate the area of formation; and thin black arrows indicate the circulation of the Barents Sea branch halocline, which affects the Northwind Ridge and site P25; the white box outlines the study site of Ortiz et al. (2009). (Based on the IBCAO map of Jakobsson, Macnab et al. 2008.)

Minolta CM-2600d ultraviolet/visible spectrophotometer (Konica Minolta, Tokyo, Japan). See Ortiz et al. (2009) for detailed procedures. Measurements were made in the visible light spectrum $(400-700 \mathrm{~nm})$, and are used as a reference for our sample subset. As the primary focus for this study, samples were selected from marine isotope stages (MIS) 3-6, as this section of the core contains the most prominent down-core glacial-interglacial peaks. The age model for this core is derived from a combination of ${ }^{14} \mathrm{C}$ and amino acid racemization (AAR) dates, and a multi-proxy correlation with other sediment cores from the western Arctic (Polyak et al. 2009). Along with the ${ }^{14} \mathrm{C}$ and AAR ages, the down-core distribution of stratigraphic indicators used to formulate the age model is 
(a)

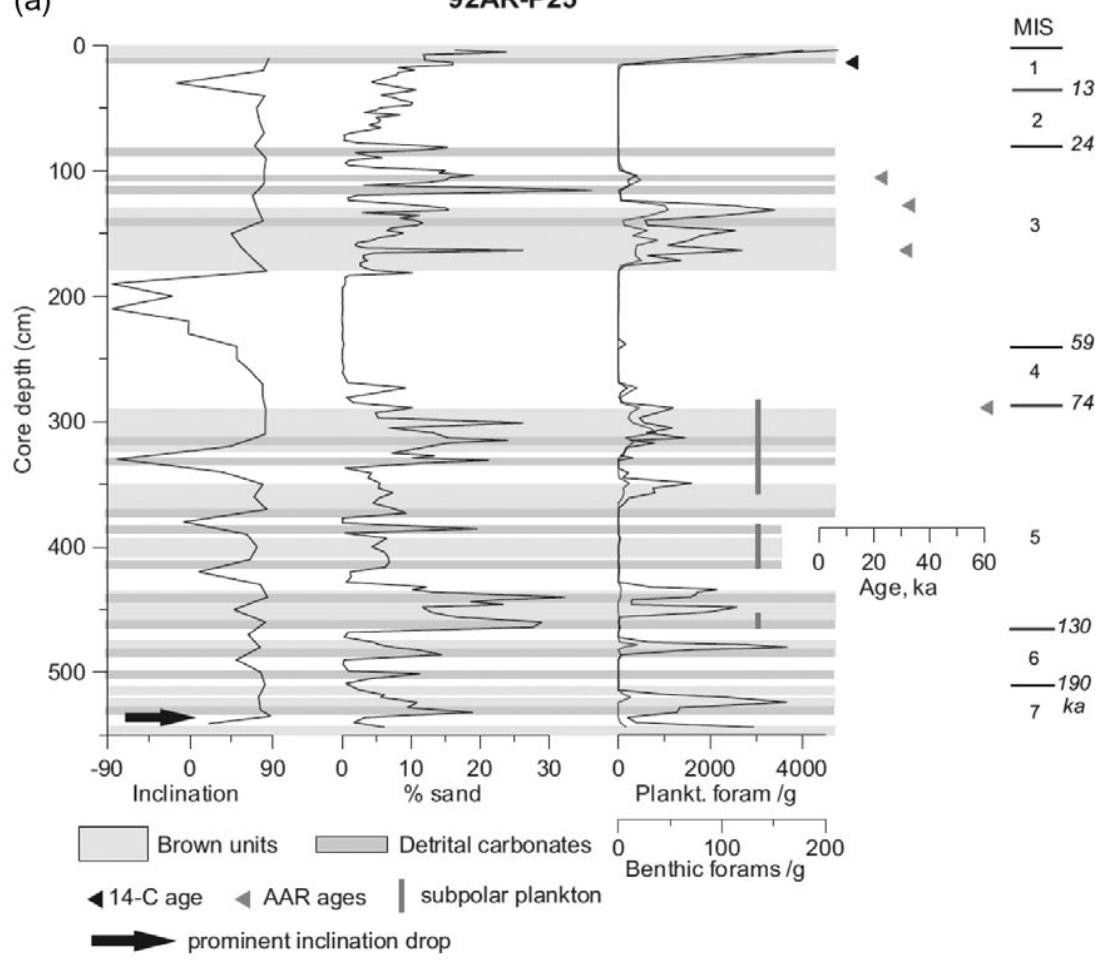

(b)

P25 Composite Age Model

Fig. 2 (a) Down-core distribution of stratigraphic indicators used by Polyak et al. (2009) to construct the age model for the core P25: palaeomagnetic inclination, sand content (>63 $\mu \mathrm{m}$ in diameter), foraminiferal numbers, and ${ }^{14} \mathrm{C}$ and amino-acid racemization (AAR) ages. Palaeomagnetic data and ${ }^{14} \mathrm{C} / \mathrm{AAR}$ ages are from Polyak et al. (2009). The prominent inclination drop has been demonstrated to occur in marine isotope stage (MIS) 7 (Polyak et al. 2009). The inferred MIS boundaries and ages are shown on the right. (b) Age-depth plot for core P25. Grey diamonds represent ${ }^{14} \mathrm{C}$ and ${ }^{14} \mathrm{C}$-calibrated AAR ages (Adler et al. 2009), and black squares represent SPECMAPcorrelated MIS picks based on multi-proxy correlation of several western Arctic cores (Polyak et al. 2009). SPECMAP MIS ages are taken from Martinson et al. (1987). The dashed line with open circles represents the composite age model for core P25.

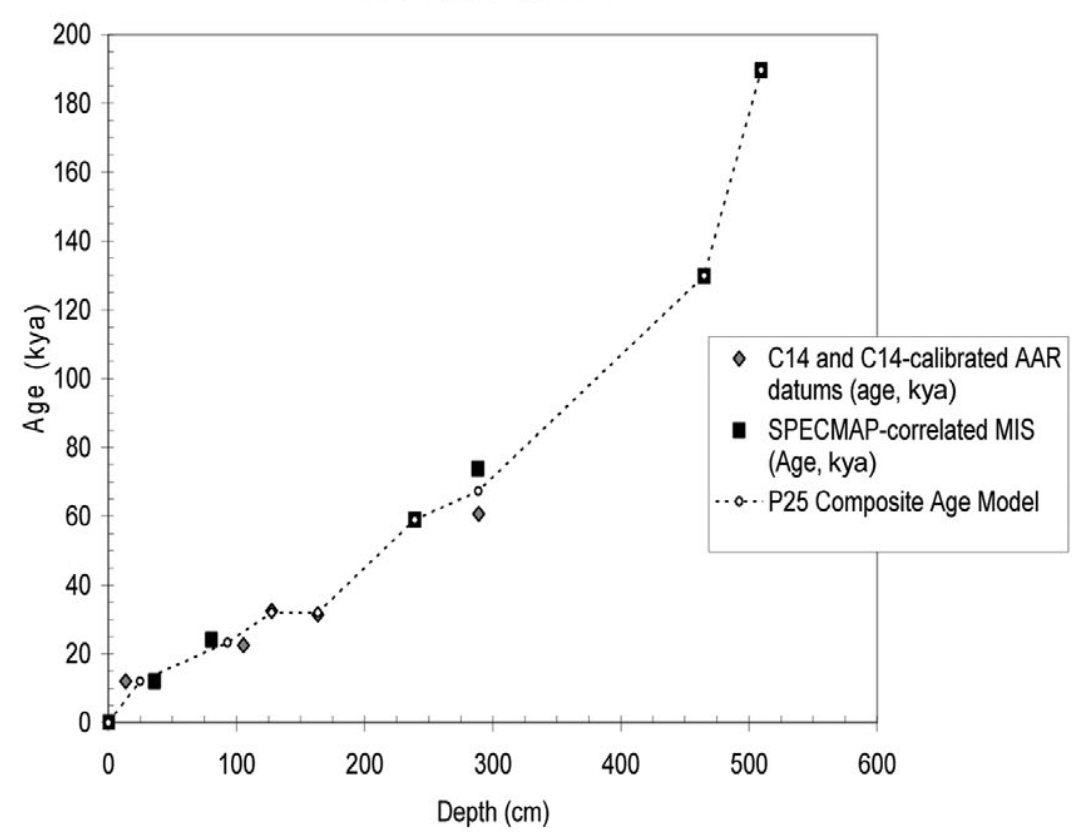

shown in Fig. 2, and include: palaeomagnetic inclination, sand content (>63 $\mu \mathrm{m}$ in diameter) and foraminiferal numbers. This age model is further confirmed by the elevated content of subpolar species among planktonic foraminifers in MIS 5, consistent with earlier results from other sites in the Arctic Ocean (Nørgaard-Pedersen et al. 2007; Adler et al. 2009), and by the prominent inclination drop demonstrated to occur in MIS 7 (Polyak et al. 2009). The ages for MIS boundaries are taken from Martinson et al. (1987). 


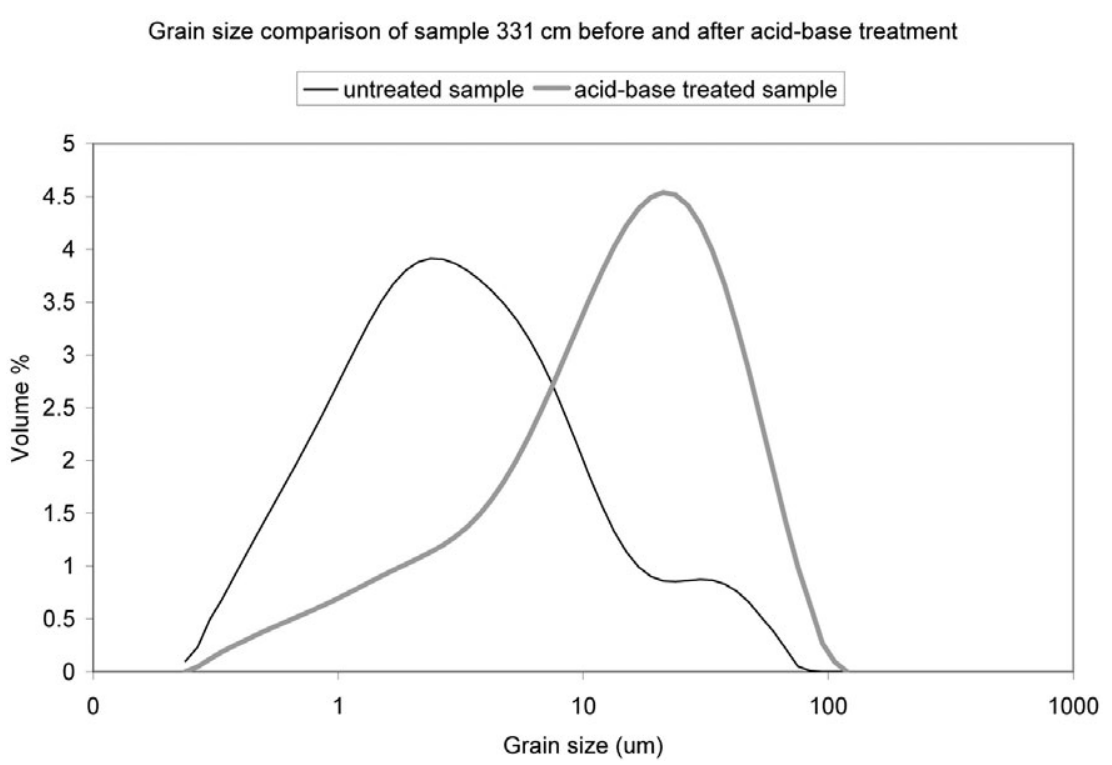

Fig. 3 Grain size spectra comparison for a sample at $331 \mathrm{~cm}$ depth showing the difference in spectra between the untreated sample and acid-base-treated sample residue, which has had any carbonate and biosilica removed. Note the decreased volume percentage of grain sizes smaller than $10 \mu \mathrm{m}$ in diameter and the shift in median grain size towards coarser grains for the acid-base-treated samples. Sample 331 was chosen for its initially high elemental $\mathrm{Ca}$ content and thus maximum potential for dissolution during acid-base treatment.
The DSR measurements were also made on the subset of discrete samples for comparison. Statistical analysis of DSR data was conducted on the siliciclastic terrigenous component, in order to extract information regarding variations in clay mineral assemblages from the carbonate-free sediment. Clay minerals have been shown to occupy geographically distinct regions in the Arctic (e.g., Clark et al. 1980; Naidu \& Mowatt 1983; Dalrymple \& Maass 1987; Darby et al. 1989; Wahsner et al. 1999; Kalinenko 2001; Viscosi-Shirley, Mammone et al. 2003; Viscosi-Shirley, Pisias et al. 2003; Stein et al. 2004; Stein 2008; Vogt 2009; Vogt \& Knies 2009), and are here used to evaluate provenance and circulation changes during glacial-interglacial periods.

The down-core samples taken from the core were mixed with $0.2 \%$ sodium hexametaphosphate, in order to avoid flocculation (McCave et al. 2005), and were washed, sieved and dried. We conducted measurements on both bulk sediment and sediment residues following an acid-base treatment. Following McCave et al. (2005), a treatment of $5 \mathrm{ml}$ of glacial acetic acid was applied to about $0.2 \mathrm{~g}$ of the dried $<63-\mu \mathrm{m}$-diameter samples, to remove carbonate, followed by about $40 \mathrm{ml}$ of $2 \mathrm{M}$ $\mathrm{Na}_{2} \mathrm{CO}_{3}$, to remove biogenic opal. The samples were then neutralized with $10 \mathrm{ml}$ of glacial acetic acid. The acid-base treatment was applied in order to isolate the terrigenous component of the fine fraction for analysis. In the process, detrital dolomite, an important constituent of Arctic Ocean sediment, was dissolved away. By comparing grain size spectra obtained with a Mastersizer 2000 particle size analyser (Malvern Instruments, Malvern, UK) before and after acid-base treatment, we infer that the detrital dolomite lost in dissolution was mostly in the fine clay size class (Fig. 3). Although grain size analysis was performed on the $<45-\mu \mathrm{m}$ diameter class for the untreated samples, and on the $<63-\mu \mathrm{m}$-diameter class for treated samples, duplicate measurements on the $<63-\mu m$-diameter class for the untreated samples demonstrated no change in grain size spectra between the $<63-\mu \mathrm{m}$ - and $<45-\mu \mathrm{m}$-diameter classes, indicating any changes between the untreated and the treated samples were the result of the acid-base treatment.

A comparison of the median grain diameter of the untreated and acid-base-treated samples allows us to calculate the relative quantity of detrital dolomite lost during treatment. This provides a means of estimating the carbonate content of the sediment, which could not be directly measured by DSR alone. This estimate is corroborated by elemental $\mathrm{Ca}$, measured by $\mathrm{X}$-ray fluorescence (XRF) using the Kent State University Innov-X alpha series handheld XRF analyser on the untreated core surface. Because foraminiferal calcite is minimal, elemental Ca predominantly represents detrital carbonate content (Polyak et al. 2009). Bulk Ca peaks consistently at the core depths with calculated dolomite loss, verifying that the acid treatment successfully isolates the terrigenous component, with the majority of sediment alteration limited to the dissolution of the dolomite constituent (Fig. 4). It appears that the maximum detrital dolomite content occurred during glacial-deglacial periods, again consistent with the record of elemental Ca and various Arctic Ocean sediment records from the literature (e.g., Darby et al. 1989; Bischof et al. 1996; Phillips \& Grantz 2001; Polyak et al. 2004; Polyak et al. 2009). 


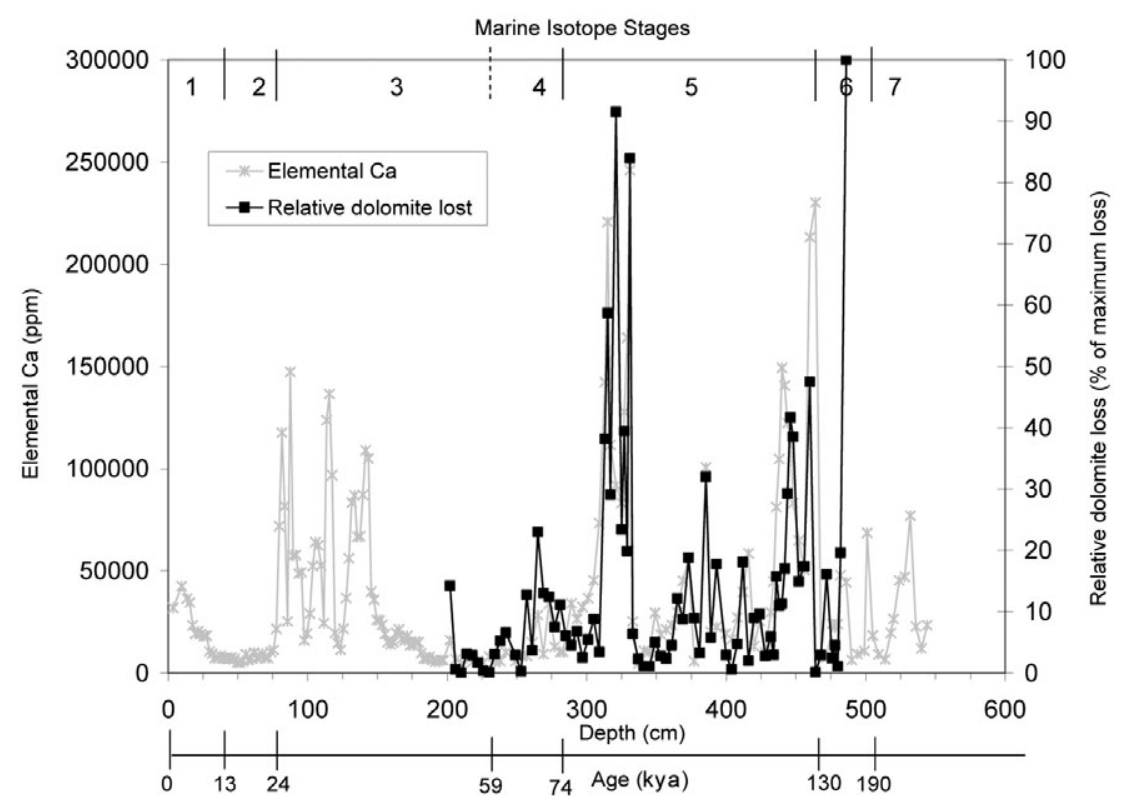

Fig. 4 Calculated estimate of detrital dolomite lost during acid-base treatment plotted against the bulk elemental Ca abundance, measured by X-ray fluorescence. The relative dolomite loss is calculated from the difference in median grain size between acid-base-treated samples and untreated whole-core samples. It is then converted to units of percentage of maximum loss by dividing by the maximum median grain size difference and multiplying by 100 . Note that $100 \%$ does not signify $100 \%$ carbonate, but rather the sample with the greatest inferred loss of dolomite. Because maximal loss occurs synchronously with $\mathrm{Ca}$ abundance, we can conclude that acid-base treatment successfully separates the siliciclastic terrigenous component of the sediment, with most sediment alteration limited to the detrital dolomite component. Note that there may be small discrepancies in depth scale between the two instruments used to measure elemental Ca abundance and grain size-based estimates of dolomite loss.

Following acid-base treatment, DSR was measured on the filtered and dried residues using a LabSpec Pro FR ultraviolet/visible/near-infrared (350-2500 nm) spectrophotometer (Analytical Spectral Devices, Boulder, CO, USA), hereafter referred to as the LabSpec Pro. The full spectra reflectance patterns were used as an estimate of mineral composition, based on a comparison of absorbance/reflectance features of the sample with a mineral standard. This method can present challenges, particularly when working with mineral assemblages, as the presence of some minerals can mask the features of others. As a more quantitative means of estimating mineral composition, we used R-mode factor analysis with Varimax rotation, which Davis (1986: 548) also calls a "principal component analysis approach to factor analysis". This is a statistical sorting and data reduction method on the visible (400-700 nm) portion of the LabSpec Pro data, to determine the major factors responsible for variation in the data set. This method has been shown to successfully identify major mineral assemblages, including clay minerals, by comparison with quantitative X-ray diffraction (qXRD) on the northern Alaskan margin (Ortiz et al. 2009) (Fig. 1), and by comparison of results from a large number of Atlantic Ocean cores with known sediment composition and general mineralogical distributions (e.g., Balsam \& Deaton 1991).
In this method, eigenvalues and eigenvectors are extracted from a standardized variance-covariance, or correlation, matrix. Then, the eigenvectors, which are calculated in normalized form, are transformed to factors, which are weighted proportionally with the level of total variance they represent. Varimax rotation works to maximize the level of variance explained by the leading factors, by repositioning the factor axes so that the loadings are either near \pm 1 or near the origin. Initial and post-rotation eigenvalues and variances explained are listed in Table 1. The significant factors were retained if their initial eigenvalues were $>1$ (indicating that they explain more of the variance than the original standardized variables) and could be distinguished from the "noise floor" on the scree plot (Fig. 5) See Davis (1986) for details on R-mode factor analysis.

The factor loadings for the leading factors (Table 2), which represent the relative importance of each variable (in this case wavelength) within the factor, were compared against a library of centre-weighted derivatives of clay mineral spectra for interpretation (Clark et al. 2003). Centre-weighted derivatives, used in order to minimize the truncation or round-off error, are calculated by the symmetrized form of the derivative equation (Press et al. 1992): 
Table 1 Eigenvalues and percentage variance for the leading factors extracted by R-mode factor analysis, before and after Varimax rotation.

\begin{tabular}{llllllll}
\hline & \multicolumn{2}{l}{ Initial eigenvalues } & & \multicolumn{3}{l}{ Eigenvalues after rotation } \\
\cline { 2 - 4 } Factor & Eigenvalue & $\%$ of variance & Cumulative \% & & Eigenvalue & $\%$ of variance & Cumulative \% \\
\hline 1 & 20.80 & 67.09 & 67.09 & & 16.29 & 52.55 & 52.55 \\
2 & 7.25 & 23.38 & 90.48 & & 7.66 & 24.72 & 77.27 \\
3 & 1.59 & 5.13 & 95.61 & & 5.69 & 18.34 & 95.61 \\
\hline
\end{tabular}

\section{Scree Plot}

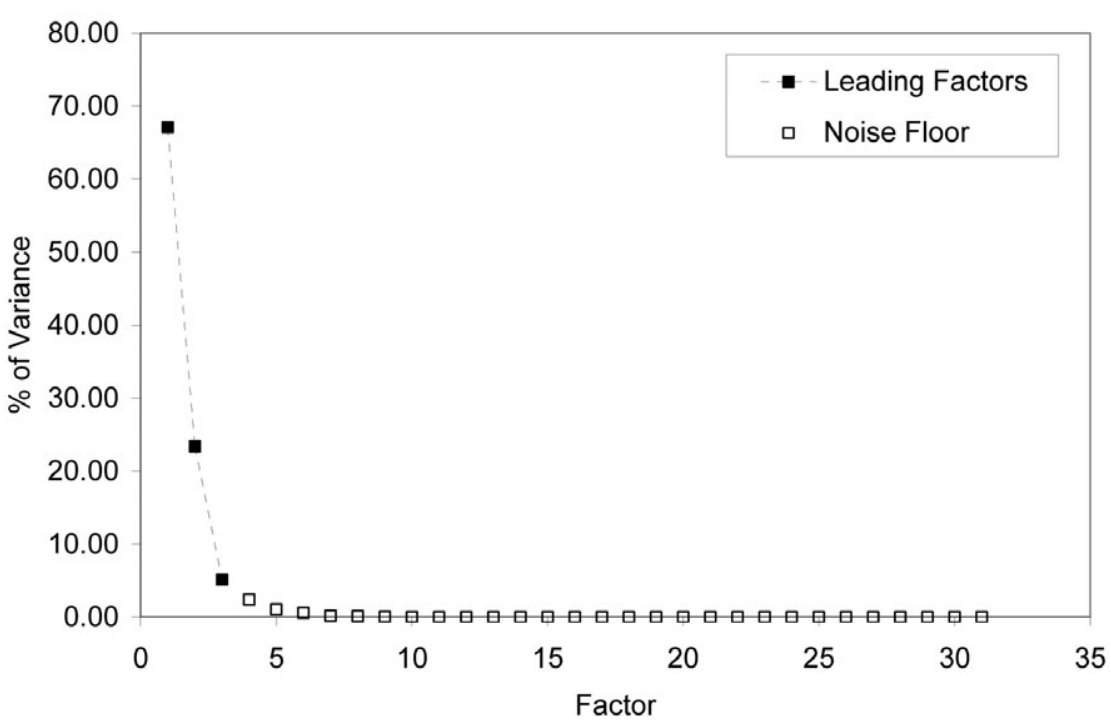

Fig. 5 Scree plot showing the initial percentage of variance explained by each factor. The leading three factors can be easily distinguished from the "noise floor".

$$
f^{\prime}(x) \approx[f(x+h)-f(x-h)] / 2 h
$$

Visible spectra are typically featureless and can be highly correlated, making it difficult to use them for mineral identification. By taking the first derivative of the spectra, we emphasize the variation or changes in slope of the spectra, making interpretation much easier (Balsam \& Deaton 1991). Balsam \& Deaton (1991) showed that first-derivative curves were consistent between samples of similar mineralogy, and that the peaks are a function of the concentration of the minerals present. They also indicate that the relationship between the relative proportion of a mineral in the sample and the first-derivative spectral peaks may not be direct, making it difficult to make judgments on the percentage composition.

Following analysis of the factor loadings, the downcore factor scores (Table 3), which represent the relative variance contributed by each factor, were plotted versus the elemental content of manganese measured by XRF of the whole core. Manganese (Mn) has been shown as an indicator for glacial-interglacial cycles in the Arctic Ocean (Jakobsson et al. 2000; Polyak et al. 2004; Löwemark et al. 2008). High Mn content in Arctic sediments has been associated with interglacial/interstadial periods, during which either the increased ventilation of deep water promotes $\mathrm{Mn}$ precipitation, or $\mathrm{Mn}$ is delivered extensively by Siberian river run-off (Phillips \& Grantz 1997; Jakobsson et al. 2000; Löwemark et al. 2008). The XRF-derived Mn variations in our samples are considered in the stratigraphic context of multi-proxy correlations between sediment cores across the western Arctic Ocean (Polyak et al. 2009).

The terms "glacial" and "interglacial" in this work should be taken to mean "glacial-type" and "interglacialtype," respectively, as described in Adler et al. (2009), indicating that the cycles observed in the Arctic do not necessarily represent full glacial-interglacial amplitudes globally. It is not fully understood why glacial-interglacial conditions are more strongly expressed in the Arctic than in other parts of the world, but it may be because of sea-ice- and snow albedo-related amplifications of precessional forcing (Adler et al. 2009, and references therein). Although the magnitude of the glacial cycles may vary, the associated changes in sea level, ice extent and circulation have a major impact on sedimentation in the Arctic Ocean. 
Table 2 Factor loadings for the leading factors extracted by R-mode factor analysis. Communalities are the sum of the squared factor loadings for each variable (wavelength). They represent the percentage variance that the leading factors explain for each variable.

\begin{tabular}{|c|c|c|c|c|}
\hline Wavelength (nm) & Factor loading 1 & Factor loading 2 & Factor loading 3 & Communality \\
\hline 400 & -0.778 & 0.106 & 0.536 & 0.903 \\
\hline 410 & -0.789 & 0.152 & 0.563 & 0.961 \\
\hline 420 & -0.792 & 0.236 & 0.543 & 0.978 \\
\hline 430 & -0.792 & 0.325 & 0.497 & 0.980 \\
\hline 440 & -0.751 & 0.362 & 0.540 & 0.987 \\
\hline 450 & -0.653 & 0.265 & 0.701 & 0.988 \\
\hline 460 & -0.440 & 0.153 & 0.852 & 0.943 \\
\hline 470 & -0.249 & 0.274 & 0.896 & 0.939 \\
\hline 480 & -0.301 & 0.595 & 0.733 & 0.982 \\
\hline 490 & -0.357 & 0.792 & 0.448 & 0.956 \\
\hline 500 & -0.374 & 0.824 & 0.340 & 0.934 \\
\hline 510 & -0.375 & 0.819 & 0.343 & 0.929 \\
\hline 520 & -0.351 & 0.812 & 0.373 & 0.923 \\
\hline 530 & -0.263 & 0.854 & 0.357 & 0.927 \\
\hline 540 & -0.014 & 0.970 & 0.177 & 0.973 \\
\hline 550 & 0.256 & 0.948 & -0.059 & 0.967 \\
\hline 560 & 0.460 & 0.807 & -0.209 & 0.907 \\
\hline 570 & 0.647 & 0.631 & -0.301 & 0.907 \\
\hline 580 & 0.795 & 0.454 & -0.323 & 0.943 \\
\hline 590 & 0.892 & 0.285 & -0.307 & 0.970 \\
\hline 600 & 0.941 & 0.146 & -0.269 & 0.980 \\
\hline 610 & 0.962 & 0.047 & -0.229 & 0.981 \\
\hline 620 & 0.970 & -0.024 & -0.201 & 0.983 \\
\hline 630 & 0.973 & -0.083 & -0.177 & 0.986 \\
\hline 640 & 0.973 & -0.132 & -0.160 & 0.989 \\
\hline 650 & 0.967 & -0.174 & -0.156 & 0.989 \\
\hline 660 & 0.958 & -0.200 & -0.170 & 0.986 \\
\hline 670 & 0.942 & -0.217 & -0.203 & 0.975 \\
\hline 680 & 0.911 & -0.217 & -0.261 & 0.945 \\
\hline 690 & 0.878 & -0.180 & -0.332 & 0.913 \\
\hline 700 & 0.872 & -0.159 & -0.359 & 0.915 \\
\hline
\end{tabular}

Varimax-rotated R-mode factor analysis (hereafter, VRFA) was also conducted on the bulk DSR measurements from the whole core, and from discrete samples, prior to acid-base treatment. These additional data sets provide a means of comparison between the whole-core data and discrete samples, as well as between untreated samples and acid-base-treated residues. Factor loadings and factor scores were compared among the three data sets to verify consistency, and to evaluate the effectiveness of the acid-base treatment.

\section{Results}

From the raw DSR data on both the untreated whole core and discrete sediment samples, the colorimetric indices $L^{*}$ (sediment brightness), $a^{*}$ (red-green contrast) and $b^{*}$ (blue-yellow contrast) were obtained and plotted together for comparison (Fig. 6). However, because the spectral range for each index is too expansive to provide information on individual mineral composition, their primary use is for stratigraphic purposes. Thus, in order to extract information regarding sediment mineralogy, VRFA was employed on the 10-nm resolution DSR data, described below. The ultraviolet/ visible/near-infrared reflectance data on the acidbase-treated samples were compared against mineral reflectance standards following VRFA of the visible portion of the spectra. The estimates of mineral composition based on comparison of absorbance/reflectance features across the 350-2500 nm wavelength spectra were consistent with the mineral assemblages extracted by VRFA.

VRFA was conducted on the 400-700 nm wavelength portion of the acid-base-treated DSR data to maintain consistency with the visible data obtained on the untreated whole core and discrete samples. In each data set, VRFA extracted three significant factors responsible for the down-core variations in DSR. Significant factors 
Table 3 Factor scores for the leading factors extracted by R-mode factor analysis.

\begin{tabular}{|c|c|c|c|}
\hline Depth $(\mathrm{cm})$ & Factor 1 scores & Factor 2 scores & Factor 3 scores \\
\hline 202 & -0.861 & -0.076 & 0.289 \\
\hline 206 & -1.021 & -0.111 & 1.213 \\
\hline 210 & -1.029 & -0.637 & 1.135 \\
\hline 214 & -1.448 & -1.328 & 1.323 \\
\hline 218 & -1.319 & -1.050 & 0.982 \\
\hline 222 & -1.396 & -1.226 & 0.816 \\
\hline 226 & -0.962 & -0.572 & 0.964 \\
\hline 230 & -1.280 & -0.597 & 0.850 \\
\hline 234 & -1.466 & -0.738 & 0.133 \\
\hline 238 & -0.921 & -0.120 & -0.930 \\
\hline 242 & -1.453 & -0.873 & -0.234 \\
\hline 249 & -1.027 & -0.695 & 0.073 \\
\hline 253 & -0.634 & 0.845 & -0.140 \\
\hline 257 & -0.542 & 1.400 & -0.527 \\
\hline 261 & -0.605 & 0.748 & 0.296 \\
\hline 265 & -0.836 & -0.767 & -1.572 \\
\hline 269 & -0.739 & 1.617 & -0.482 \\
\hline 273 & -0.429 & 1.414 & -0.555 \\
\hline 277 & -0.470 & 1.440 & -0.627 \\
\hline 281 & -0.730 & 0.254 & -0.075 \\
\hline 285 & -0.371 & 0.118 & 0.096 \\
\hline 289 & 0.617 & -2.606 & -1.783 \\
\hline 293 & 1.165 & -0.884 & -0.255 \\
\hline 297 & 0.592 & -2.310 & -1.800 \\
\hline 301 & 0.944 & -0.100 & 0.108 \\
\hline 305 & 0.587 & 0.280 & -0.749 \\
\hline 309 & 0.815 & 0.618 & 0.329 \\
\hline 313 & 0.173 & 0.121 & -0.417 \\
\hline 315 & -1.083 & -0.885 & -1.498 \\
\hline 317 & 0.068 & -0.176 & 0.403 \\
\hline 321 & -0.659 & -0.497 & 0.270 \\
\hline 325 & -0.082 & -0.748 & 0.073 \\
\hline 327 & -0.359 & -0.188 & -0.908 \\
\hline 329 & -0.281 & 0.120 & -0.790 \\
\hline 331 & -1.386 & -0.315 & -1.351 \\
\hline 333 & -0.292 & 0.050 & 0.684 \\
\hline 337.2 & -0.483 & -0.886 & 0.069 \\
\hline 341 & -0.613 & -0.299 & 2.416 \\
\hline 345 & 0.187 & 2.189 & 0.271 \\
\hline 349 & 1.138 & 0.030 & 0.511 \\
\hline 353 & 1.588 & 0.079 & 0.856 \\
\hline 357 & 1.202 & -2.163 & -1.508 \\
\hline 361 & 1.834 & 0.084 & 0.504 \\
\hline 365 & 1.188 & 0.244 & 0.347 \\
\hline 369 & -0.311 & 0.388 & -1.066 \\
\hline 373 & -0.356 & 0.399 & -1.593 \\
\hline 377 & -1.102 & -0.753 & 2.205 \\
\hline 381 & -0.480 & -0.574 & 0.540 \\
\hline 385.5 & -0.523 & 1.322 & 0.069 \\
\hline 389 & -0.076 & 0.939 & 0.331 \\
\hline 393 & 1.497 & -0.357 & -0.028 \\
\hline 400 & 2.208 & -1.835 & -0.766 \\
\hline 404 & 2.398 & -0.712 & 0.442 \\
\hline 408 & 1.685 & 0.158 & 0.592 \\
\hline 412 & 0.350 & 1.003 & 0.524 \\
\hline 416 & -0.191 & 0.422 & 0.521 \\
\hline 420 & 0.370 & 1.773 & 0.730 \\
\hline 424 & -0.471 & 1.354 & -1.461 \\
\hline 428 & 0.098 & 0.743 & 0.391 \\
\hline 432 & 1.554 & -0.473 & -0.213 \\
\hline 434 & 1.682 & 0.386 & 0.937 \\
\hline 436 & 1.310 & 0.947 & 1.212 \\
\hline 438 & 0.736 & 0.847 & 0.373 \\
\hline 440 & 0.206 & 0.634 & -1.653 \\
\hline 442 & 0.396 & 1.116 & 0.371 \\
\hline 444 & -0.024 & 0.341 & 0.823 \\
\hline 446 & 0.532 & 0.075 & -0.613 \\
\hline 448 & 0.162 & 0.054 & 0.419 \\
\hline 452 & 0.108 & 0.624 & 0.443 \\
\hline 456 & -0.884 & 1.831 & 0.423 \\
\hline 460.2 & -0.635 & 1.574 & -1.449 \\
\hline 464 & -0.811 & 1.182 & -2.521 \\
\hline 468 & -0.854 & -1.853 & 0.024 \\
\hline 472 & -0.896 & -1.677 & 2.814 \\
\hline 476.2 & 1.620 & -0.780 & -0.144 \\
\hline 478 & 1.724 & -0.677 & -0.144 \\
\hline 480 & 1.263 & 0.690 & 0.669 \\
\hline 482 & 1.167 & 0.676 & 0.202 \\
\hline 486 & -0.772 & -0.592 & -2.213 \\
\hline
\end{tabular}

were defined as those with eigenvalues greater than one, and with a percentage variance that could be distinguished from the noise floor in the scree plot (Fig. 5). Here, we compare the VRFA of the whole-core DSR with that of the acid-base treated samples. VRFA of a subset of the untreated discrete samples from the same depth interval as the acid-base-treated samples yielded very similar results to the VRFA of the whole-core DSR, suggesting no real differences arise from a decrease in sample size. This allows us to infer that any differences between the wholecore data and treated samples are the result of the acidbase treatment.

Comparison of the factor loadings from the VRFA for the whole-core data and the acid-base-treated samples are shown in Fig. 7. The major difference between the two is a redistribution of variance between factors 1 and 2. That is, the loadings for factor 1 of the treated samples are comparable with the loadings for factor 2 of the untreated whole core, and vice versa. Factor 3 has a very similar shape for each, but is inverted in the untreated whole core relative to the acid-base-treated samples. Because the functions extracted by VRFA are orthogonal, a redistribution of the variance could result in a difference in the rotation or order of the factors extracted. The loadings can also be dependent on the number of factors extracted and rotated (Davis 1986).

Minor differences between untreated and treated factor loadings include stronger loadings for untreated factors 1 and 2 between ca. 400 and $540 \mathrm{~nm}$, whereas untreated factor 3 has slightly weaker loadings, except for a peak at ca. $470 \mathrm{~nm}$. Untreated factor 3 also has weaker loadings than treated factor 3 at ca. $580 \mathrm{~nm}$. Untreated factors 1 and 3 have stronger loadings between ca. 650 and $700 \mathrm{~nm}$, whereas untreated factor 2 has weaker loadings in this interval. These differences may arise from the dissolution of clay-sized carbonate (as interpreted from the grain-size data), such as dolomite, during acid-base treatment, unmasking the reflectance properties of less abundant clays, and thus amplifying their signals. The slight redistributions in variance between factors may have contributed to the offsets as well.

Using a correlation matrix, the VRFA factor loadings for the acid-base-treated samples were compared with symmetric first-derivative transformations of a library of silt and clay mineral DSR signatures provided by the US Geological Survey (Clark et al. 2003) and the Kent State University (KSU) Spectral Library (as used in Ortiz et al. [2009]). Factor 1 correlated with the reflectance signature of a smectite + chlorite clay assemblage, with a correlation fit of $r=-0.98$ (Fig. 8a). The first-derivative smectite + chlorite spectrum was derived from the spectral standard for a mixture of these minerals provided by the US Geological Survey Spectral Library version 5 (Clark 
Fig. 6 Colorimetric indices $L^{*}$ (sediment brightness; top), $a^{\star}$ (red-green contrast; middle) and $b$ * (blue-yellow contrast; bottom) for the whole-core surface and the discrete samples.
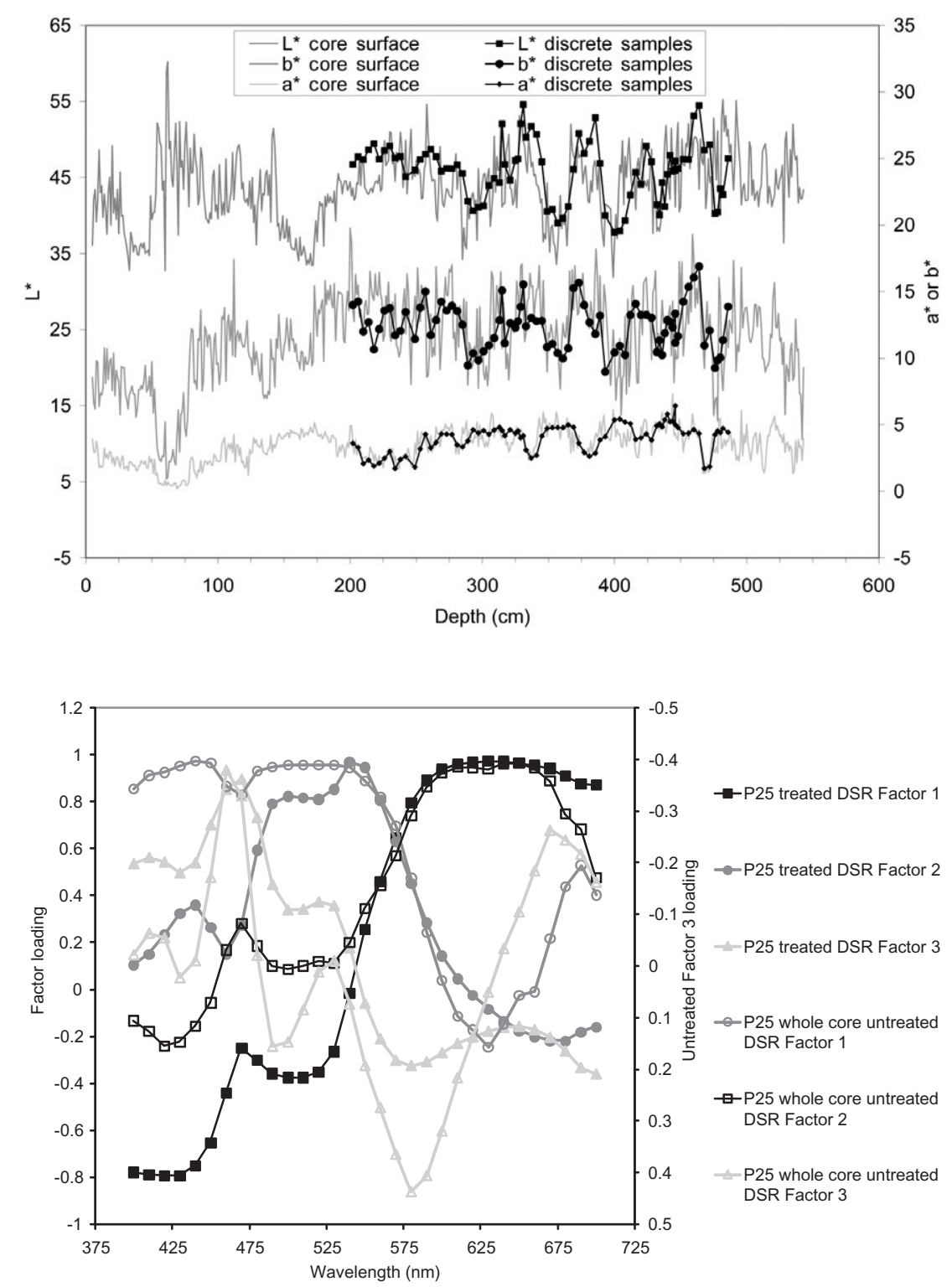

Fig. 7 Diffuse spectral reflectance (DSR) Varimax-rotated R-mode factor analysis (VRFA) factor loadings for the acid-base-treated samples, plotted with the VRFA factor loadings for the untreated whole-core DSR. Treated factor 1 (black line with filled squares) corresponds to untreated factor 2 (black line with open squares). Treated factor 2 (darkgrey line with filled circles) corresponds to untreated factor 1 (dark-grey line with open circles). Treated factor 3 (light-grey line with filled triangles) corresponds to untreated factor 3 (light-grey line with open triangles). Differences between untreated whole-core loadings and treated sample loadings are described in the text. et al. 2003). Factor 2 correlated with the illite + goethite signature, with $r=0.90$ (Fig. 8b). The first-derivative illite + goethite standard (KSU Spectral Library, as used in Ortiz et al. [2009]) was calculated as a 50/50 numerical average of the spectra for the minerals illite and goethite, which were verified by XRD at KSU (Carlson, pers. comm. 2009). Factor 3 correlated with the signature for glauconite, with $r=0.97$ (Fig. 8c). The glauconite signature was determined by a first-derivative transformation of the spectral standard measured by the LabSpec Pro at KSU for a known glauconite sample, which was corroborated by comparison of the raw reflectance curve with that provided for glauconite by the US Geological Survey Spectral Library version 5 (Clark et al. 2003). These three factors, smectite + chlorite $(52.5 \%)$, illite + goethite $(24.7 \%)$ and glauconite $(18.3 \%)$, are responsible for $95.5 \%$ of the total variation (Table 1). When plotted against the Mn proxy for glacial-interglacial cycles, factor 1 , hereafter smectite + chlorite, varied directly with elemental Mn content, peaking synchronously with Mn (Fig. 9a), and factor 2, hereafter illite + goethite, varied inversely with Mn content, peaking during low Mn (Fig. 9b). Factor 3, hereafter glauconite, demonstrated a higher frequency of variability, more indicative of millennial rather than glacial-interglacial time scales. However, the maximum glauconite scores appear to occur mostly during periods of low Mn, or during transitions between low and high Mn levels (Fig. 9c). 
(a)

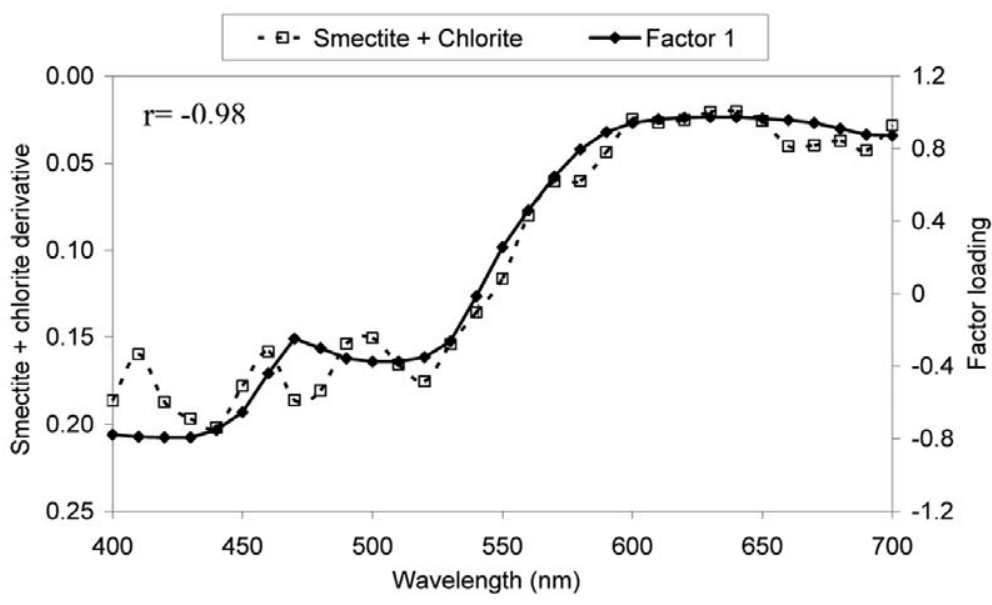

(b)

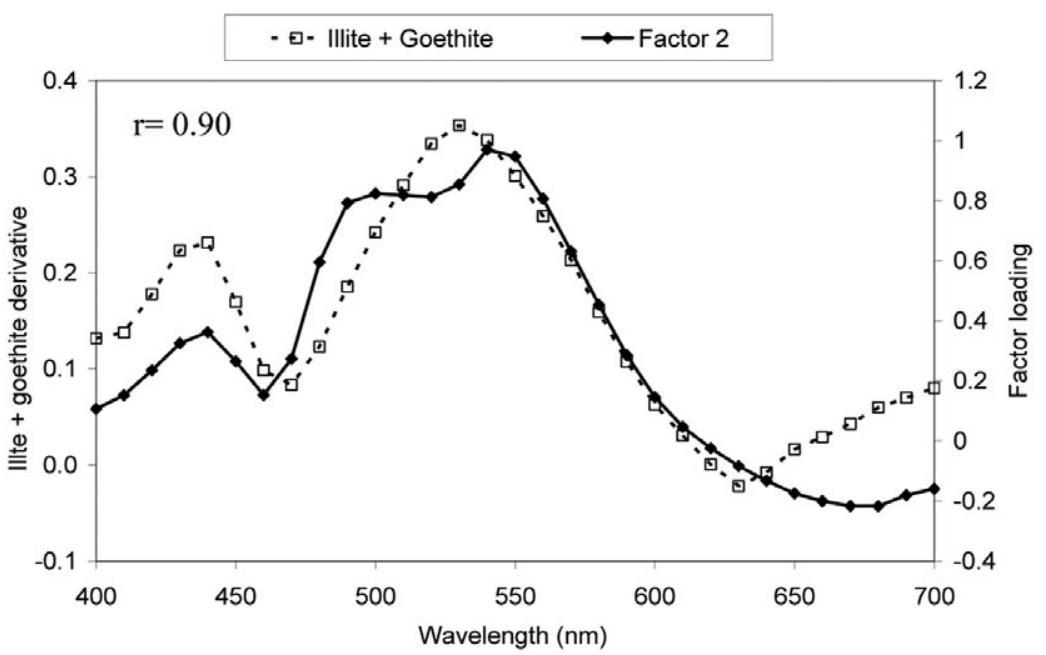

(c)

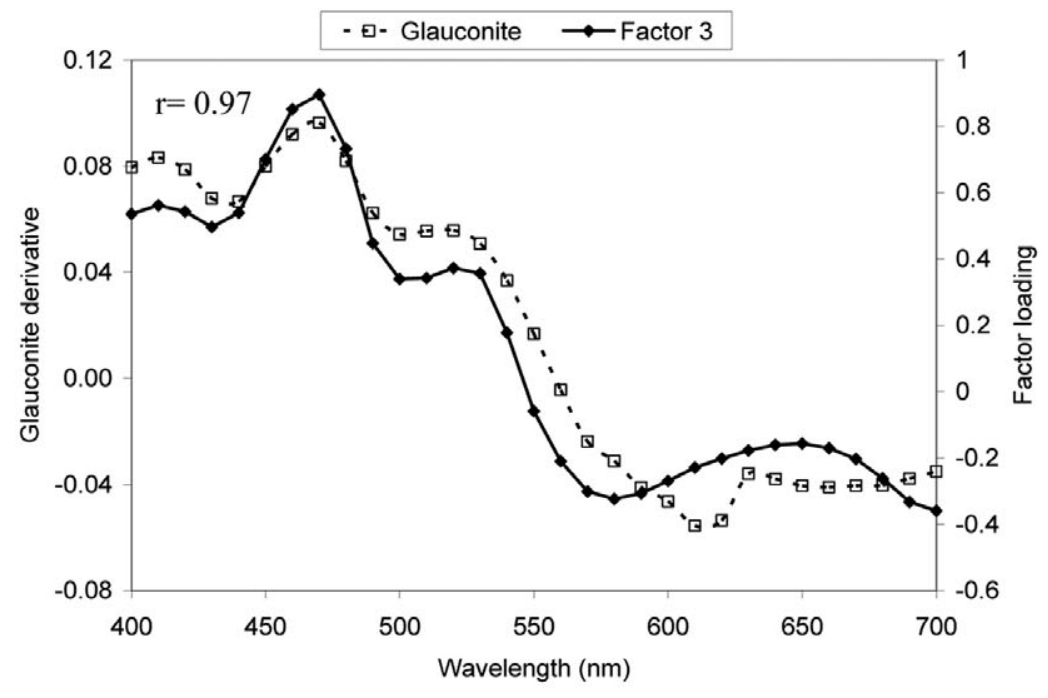

Fig. 8 (a) Factor 1 spectrum versus smectite + chlorite standard. (b) Factor 2 spectrum versus illite + goethite standard. (c) Factor 3 spectrum versus glauconite standard. Spectral standards provided by Clark et al. (2003) and the Kent State University Spectral Library (as used in Ortiz et al. [2009]). 
(a)
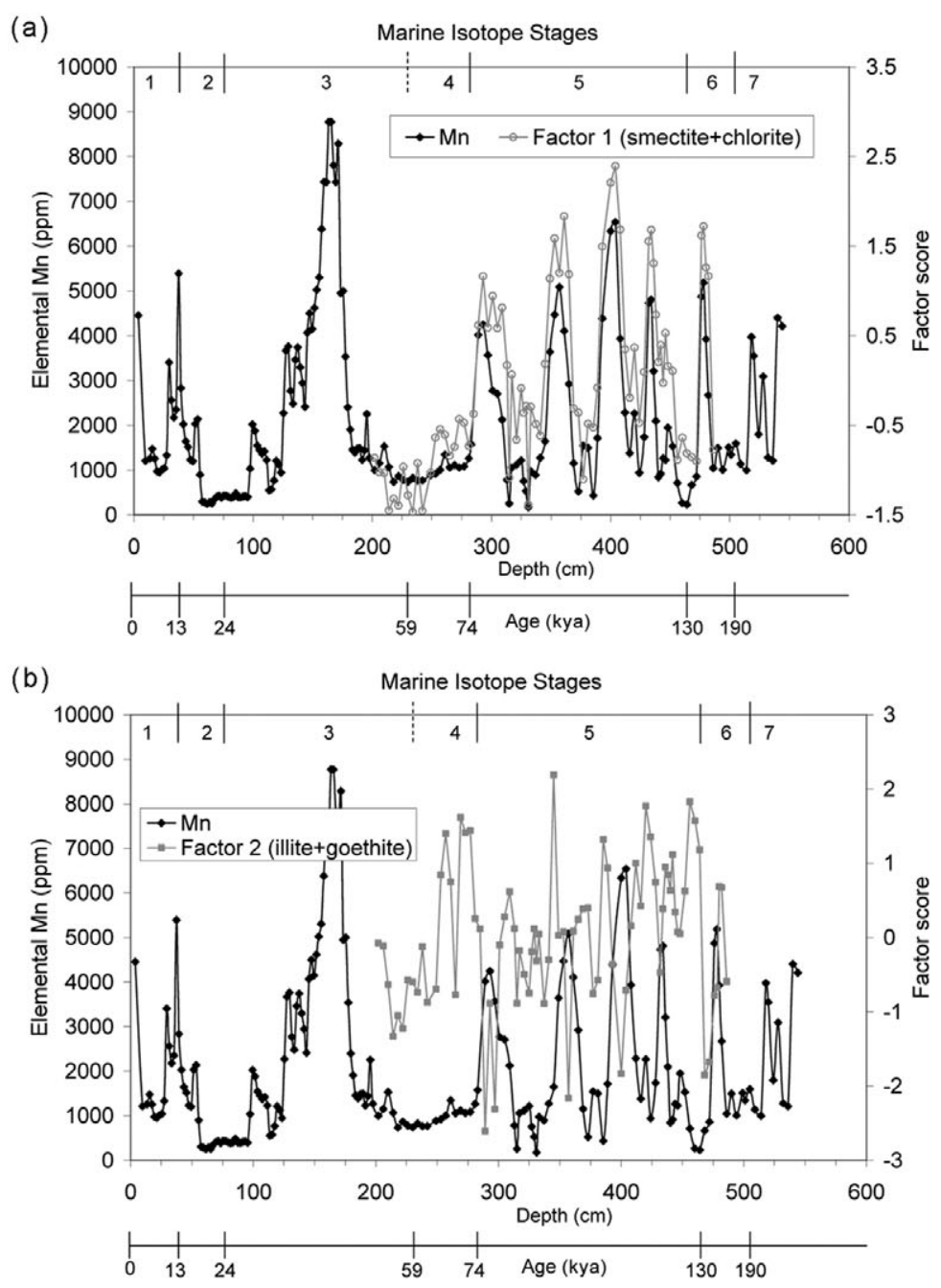

Fig. 9 (a) Down-core variability of factor 1 (smectite + chlorite) plotted against Mn proxy for glacial-interglacial cycles: illustrates the importance of smectite + chlorite deposition during interglacials. (b) Down-core variability of factor 2 (illite + goethite) plotted against Mn proxy for glacial-interglacial cycles: illustrates the importance of illite + goethite deposition during glacials. (c) Down-core variability of factor 3 (glauconite) plotted against Mn proxy for glacial-interglacial cycles: illustrates the higher frequency variability of glauconite in relation to the glacialinterglacial Mn cycles. Glauconite deposition is interpreted to be most important during glacial and deglacial intervals. Also marked are the marine isotope stage (MIS) boundaries, and their associated ages. The dashed line at the MIS $3 / 4$ boundary indicates an approximate depth for this boundary.

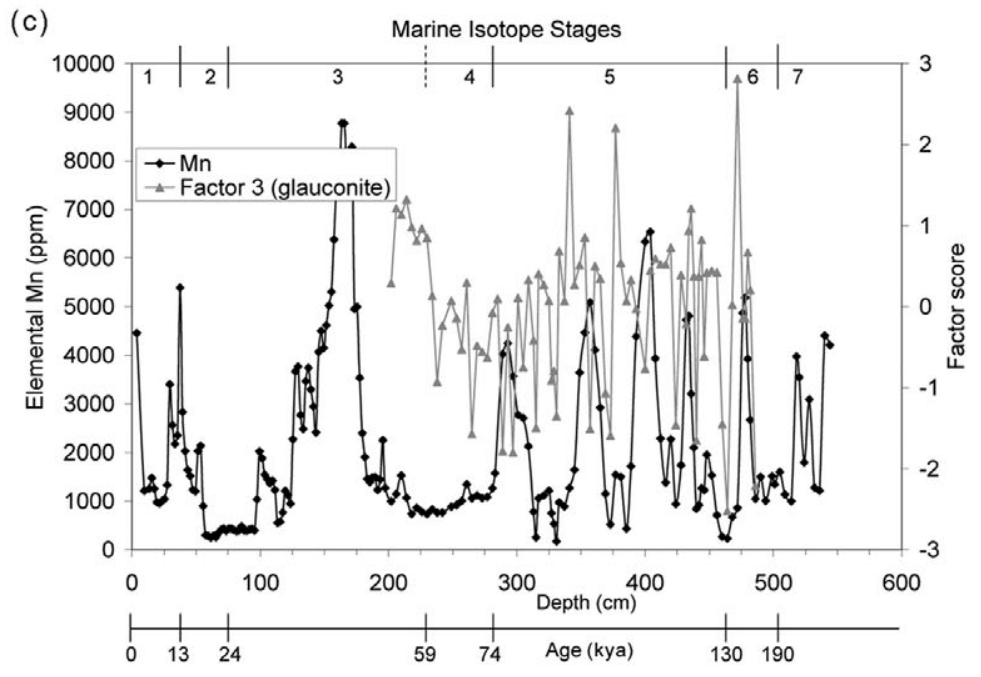




\section{Discussion}

\section{Smectite and chlorite: interglacial minerals from the eastern Arctic and Bering Sea}

When compared against the Mn cycles, the factor score for smectite + chlorite covaries with maximum elemental Mn (Fig. 9a), which is interpreted to indicate interglacial periods. This is consistent with findings of smectite + chlorite maxima during interglacials in cores from various areas of the Arctic Ocean, including the Northwind, Mendeleev, Alpha and Lomonosov ridges (Ortiz et al. 2006; Ortiz et al. 2007). We propose several possible explanations for this distribution.

First, the major sediment source regions for both smectite and chlorite to the Arctic Ocean were largely cut-off during glacial periods. For example, the Bering Sea is known as an important chlorite province and a likely source area for chlorite north of the Bering Strait (Kalinenko 2001). Smectite may also have been present in the Bering Strait region as continental run-off from volcanic rocks of eastern Siberia and southern Alaska (Naidu \& Mowatt 1983; Viscosi-Shirley, Mammone et al. 2003; Darby \& Bischof 2004). However, the Bering Sea source operated only during interglacials and major interstadials, as the Bering Strait (50 m deep) was subaerially exposed at low sea levels. Alternatively, chlorite, as well as major smectite sources, exists along the Siberian Arctic margins. According to Viscosi-Shirley, Mammone et al. (2003), chlorite can be found in the East Siberian and Chukchi seas (although a specific source is not discussed). Dethleff etal. (2000) also note that the suspended particulate material of the Yana River is enriched in chlorite. Finally, it is well established that smectite is prevalent in the western Laptev and Kara seas (Kalinenko 2001; Winkler et al. 2002; Viscosi-Shirley, Mammone et al. 2003; Vogt \& Knies 2008). A volcanically derived clay mineral, smectite is sourced primarily from the Mesozoic Siberian trap basalts of the Putorana Mountains, from where it is drained by north-flowing rivers, mostly by the Yenisey River drainage system. During Pleistocene glacial maxima, large ice sheets blocked the rivers, preventing the riverine transport of sediments from the Putorana to the Laptev and Kara seas (Mangerud et al. 2004; Svendsen et al. 2004; Vogt \& Knies 2008). Because smectite + chlorite maxima occur in P25 in all interglacial intervals, including periods of low sea level, we believe that these minerals are primarily related to Siberian rather than Pacific provenance, which is consistent with the major source of Mn (Hölemann et al. 1999). Nevertheless, smectite and/or chlorite may also have been redeposited to the study area during sea level falls from the Chukchi shelf.
Delivery of smectite and chlorite to the P25 site during interglacial periods could occur by two potential processes: ocean currents or sea-ice rafting. According to Viscosi-Shirley, Pisias et al. (2003), sediments derived from eastern Siberia and from the Bering Sea inflow are prevalent in the modern Chukchi Sea, where there is significant sediment transport via water circulation. Finegrained silts and clays, which certainly include chlorite and smectite, can be suspended and transported by Chukchi shelf current velocities (McManus et al. 1969). Northward-flowing currents dominate all water depths, and are directed through a number of submarine valleys, which exit into the southern Canada Basin (ViscosiShirley, Pisias et al. 2003; Darby \& Bischof 2004). Pickart (2004) also described the "Beaufort shelfbreak jet" as part of the Alaskan Coastal Current, which is an eastwardflowing current that carries Chukchi waters to the basin. In addition, Pacific waters that flow into the Chukchi Sea become cooler and saltier during sea-ice formation, and form descending plumes that penetrate deep into the Canada Basin (Jones 2001; Williams et al. 2008). This could provide a mechanism for transport of chlorite and smectite to the Northwind Ridge.

Also, smectite delivery could occur via the subsurface Atlantic layer circulation, from as far as the Kara Sea, because smectite-rich silts and clays brought in via rivers can become incorporated into surface and intermediate waters (Vogt \& Knies 2008). This water is carried eastward along the Siberian margin, and then enters the subsurface circulation that extends to all Arctic Ocean basins, including the southern Canada Basin (Jones 2001; Rudels et al. 2004) (Fig. 1). In the Fram Strait region, the clay fraction has been shown to be transported over significant distances as a suspended load, possibly even bringing smectite from as far as the Iceland-Faeroe Ridge (Winkler et al. 2002; Vogt \& Knies 2009). However, it is unlikely that this smectite could reach the much further away Canada Basin, because this would require some type of autosuspension in order to prevent these clays from settling over such distances, a process that is unlikely to occur in weak currents such as the Atlantic Intermediate Current. Most smectite-enriched sediments in the Arctic Ocean are more likely to be sourced from the western Laptev and Kara seas (Vogt \& Knies 2009).

The other important process for the transport of sediment to the Arctic Ocean is sea-ice rafting. There is significant evidence that smectite-rich sediment is transported via sea ice from the shelves of the Laptev and Kara seas (Dethleff et al. 2000; Winkler et al. 2002; Vogt \& Knies 2008). Fe grain matching has shown Siberian sediments in Pleistocene cores from the western Arctic, providing evidence of a circulation pattern that brings sea ice from the Laptev and Kara seas into the BG on a 
regular basis (Darby \& Bischof 2004; Darby et al. 2006). Also, sampling of dirty ice has revealed Siberian sediments from the Laptev and Kara seas in modern ice floes in the BG (Darby 2003; Darby et al. 2006). The transport of these modern ice floes to the Canada Basin is attributed to a change in circulation patterns caused by a shift in the AO, which will be discussed in detail later.

\section{Illite and goethite: glacial/deglacial pulses from north-western Canada}

The factor score for illite + goethite demonstrates an inverse correlation with $\mathrm{Mn}$ content, reaching maxima during glacial periods (Fig. 9b). This pattern is consistent with results by Ortiz and coworkers (Ortiz et al. 2006; Ortiz et al. 2007), in which peaks of illite in cores from across the central Arctic Ocean coincide with inferred glacial maxima, whereas goethite seems to co-occur with glacial to interglacial transitions.

Although illite is the most common clay mineral in Arctic shelf sediments, and is very abundant in both the Chukchi and Beaufort seas (Naidu \& Mowatt 1983; Kalinenko 2001), in the central Arctic Ocean, it seems to be particularly abundant during glacial periods (Ortiz et al. 2006; Ortiz et al. 2007). This pattern is probably, at least partly, the result of diminished deposition of other types of clays (smectite and chlorite) at these times, as a result of different transportation pathways and/or source areas and processes during glacials and interglacials. During glacial events, the Arctic was a very different environment. The ocean itself was reduced in size by as much as $50 \%$ because of the low glacial sea level, and shallow Arctic shelves were either subaerially exposed or covered by ice sheets, which existed around much of the periphery of the Arctic Ocean (Darby et al. 2006, and references therein). This also meant a limited connection with the rest of the world's oceans and complete isolation from the Pacific. There were also, presumably, greater expanses of thick sea-ice coverage or even ice shelves over large parts of the central Arctic Ocean (Phillips \& Grantz 2001; Darby et al. 2006; Bradley \& England 2008; Jakobsson, Polyak et al. 2008). In contrast, during deglaciations and ice-sheet surging events, the Arctic Ocean hosted armadas of icebergs, which played a major role in sediment transport and deposition (Darby \& Zimmerman 2008). All of these factors contribute to drastically altered sedimentation regimes in comparison with modern-type, interglacial environments.

So, there are a number of reasons why the source of sediment to the Canada Basin might be predominantly from North American provenance during glacials, including thick pack ice covering large portions of the central Arctic Ocean (Phillips \& Grantz 2001; Darby et al. 2006), possible changes to the general Arctic circulation patterns (Darby \& Bischof 2004; Darby et al. 2006) and a voluminous discharge from the Laurentide Ice Sheet (Bigg \& Wadley 2001; Darby et al. 2002; Darby \& Zimmerman 2008).

In modern environments, north-western Canada, particularly the shelf off Banks Island, is the primary source region for ice-rafted sediment deposited on the Northwind Ridge, especially during times when circulation promotes an enhanced BG (Darby \& Bischof 2004; Darby et al. 2006). This sediment has a large component of till that was deposited during the Laurentide ice-sheet expansions (Bischof et al. 1996). Illite is also common along the shorelines and within sediments off the Mackenzie River delta (Kalinenko 2001), derived to a considerable extent from glacial or periglacial deposits. Such deposits are a likely source of illite as this clay mineral is commonly formed by fragmentation of micas during mechanical weathering, although it may also be derived from hydrolysis of smectite (Deconinck et al. 2001). During glaciations, the flux of glacially eroded material to the Canada Basin was obviously much higher than at present, which may have raised the content of illite in the clay mineral fraction. For a comparison, a large peak in illite concentration in the Eurasian Basin sediments was related to a pronounced pulse of meltwater and iceberg discharge from the collapsing Saalian ice sheets (Knies \& Vogt 2003). Similar events were common for the northern margin of the Laurentide Ice Sheet, as evidenced by stable-isotope and ice-rafteddetritus records across the western Arctic Ocean (Poore et al. 1999; Darby et al. 2006; Polyak et al. 2007; Polyak et al. 2009; Darby \& Zimmerman 2008).

Goethite is not commonly studied in Arctic sediments, and we cannot conclude on its origin in sediment cores from the Northwind Ridge, as well as other sites from the central Arctic Ocean, at this time. Goethite has been documented in soils of northern Alaska (Hill \& Tedrow 1961), and has been described as a product of basalt weathering in Greenland (Mørup et al. 1990). It can also form diagenetically in marine sediments, and may even be the dominant diagenetic precipitate in these environments (van der Zee et al. 2003). The identification of goethite peaks at the glacial-interglacial transitions in Arctic sediment cores (Ortiz et al. 2006; Ortiz et al. 2007) suggests that goethite was likely related to discharge of meltwater and icebergs during ice-sheet collapses, but the provenance is not yet fully understood.

\section{Glauconite: deglacial input from the North Slope of Alaska?}

Glauconite forms by the diagenetic alteration of biotite and other clays in low-oxygen marine environments, but 
can also be detrital (Grim 1968). Its presence in Arctic sediment is not well established, partly because it produces many of the same diffraction peaks as illite for oriented clay mineral X-ray diffraction analysis (Moore \& Reynolds 1997). Its presence here is inferred from the comparison of the reflectance signature in the visible and near-infrared of this mineral in standards and samples from core P25. Analysis of the down-core scores for glauconite indicates that this mineral has a higher frequency variability than the glacial-interglacial cycles defined by Mn (Fig. 9c). When plotted against the factor scores for smectite + chlorite and illite + goethite, it appears that glauconite reaches maxima on transitions between the other two factors, namely, after illite + goethite. Occasionally, it seems to follow illite + goethite somewhat more closely. We thus propose that glauconite deposition is most significant during late glacial or deglacial periods.

Because of the apparently limited distribution of glauconite in Arctic marine sediment, we infer that it has a relatively proximal provenance. A potential local source of glauconite is the North Slope of Alaska (Fig. 10). At least two glauconite-bearing source rocks are known from the North Slope, the Triassic Shublik formation (Parrish et al. 2001) and the Lower Cretaceous Kemik Sandstone (Macquaker et al. 1999). Studies of modern dirty ice samples have indicated that the Alaskan nearshore is not a significant source of sediment to the ice in this region at present (Darby 2003), but this may not have been the case in the past when the sea level was lower. Several studies have indicated northern Alaska as a potential source region for sediments on the Beaufort shelf (Naidu et al. 1971; Rodeick 1979; Reimnitz et al. 1993). Darby (1975) indicated Mesozoic sedimentary rocks from the North Slope as the source of kaolinite clay in central Arctic samples. This evidence suggests that the Mesozoic glauconite source rocks from this region could have provided glauconite-rich sediment to the Beaufort shelf, and ultimately to the P25 site. Alternatively, the glauconite in P25 may be related to dolostone clasts, which were found to contain glauconite in cores from the Beaufort Sea and Northwind Ridge (Phillips \& Grantz 1997, 2001). Many studies indicate the north-western Canadian Arctic Archipelago as the most likely provenance region for dolostone clasts, which form distinct layers in glacial and deglacial intervals in sediment cores from the western Arctic Ocean (Darby 1975; Bischof et al. 1996; Phillips \& Grantz 2001).

Unlike the first two VRFA factors, glauconite was not observed in the DSR study of sediment cores from the central Arctic Ocean (Ortiz et al. 2006; Ortiz et al. 2007), which included P25 as a small fraction of the total samples analysed. It is quite possible that glauconite is present in these cores, but was missed because the pres- ence of dolomite and/or organics partially masked its reflectance signature. Alternatively, the relatively low abundance of this mineral phase, which should be concentrated in marginal marine sediment, may not have been great enough in abundance to be included in the leading factors. The dissolution of dolomite and concentration of the residual phases present in response to the acid-base treatment applied to our samples most likely explains the detection of glauconite by DSR. This is supported by our comparison of the factor loadings from the untreated whole-core DSR measurements with those from the acid-base-treated samples. The glauconite reflectance/absorbance features are still identifiable in the untreated factor 3, but the overall loadings do not correlate well with glauconite. This results from slightly weaker loadings through a large part of the untreated factor 3 spectrum (ca. 400-625 nm), which may partially result from the stronger absorbance of dolomite through much of this interval, as well as the very strong loadings in the red end of the spectrum (ca. 650-700 nm), possibly pointing to the presence of biogenic opal or certain organics, which can have strong reflectance peaks in that portion of the spectrum (Yacobi \& Gitelson 2000; Han 2005).

\section{Possible causes for circulation and provenance changes}

As previously discussed, conditions in the Arctic Ocean and its periphery were very different between glacial and interglacial intervals, profoundly altering the sedimentation regime. During glaciations, any sedimentary input from the Bering Sea/Pacific Ocean (smectite and chlorite) was completely blocked by exposure of the Bering Strait. Similarly, large sediment sources to the Laptev and Kara seas, the $\mathrm{Ob}$ and Yenisy rivers, were dammed by ice sheets (Mangerud et al. 2004; Svendsen et al. 2004; Vogt \& Knies 2008; Polyak et al. 2008). Even if occasional surges of river discharge occurred during glacials, providing smectite and chlorite sediments to the Siberian seas, large, grounded ice sheets existing over the Chukchi Borderland (Polyak et al. 2001; Jakobsson et al. 2005; Polyak et al. 2007), including the Northwind Ridge, would have blocked or impeded sea ice or other means of transport to the location of core P25 on the Northwind Ridge. However, these large ice floes, likely originating from the north-west portion of the Laurentide Ice Sheet (Polyak et al. 2001; Jakobsson et al. 2005; Polyak et al. 2007), could have easily transported glacially-eroded illite clays from Canadian provenance regions (Darby \& Bischof 2004; Darby et al. 2006).

During the deglaciation, ice sheets began to melt, massive meltwater input via northward-flowing rivers 


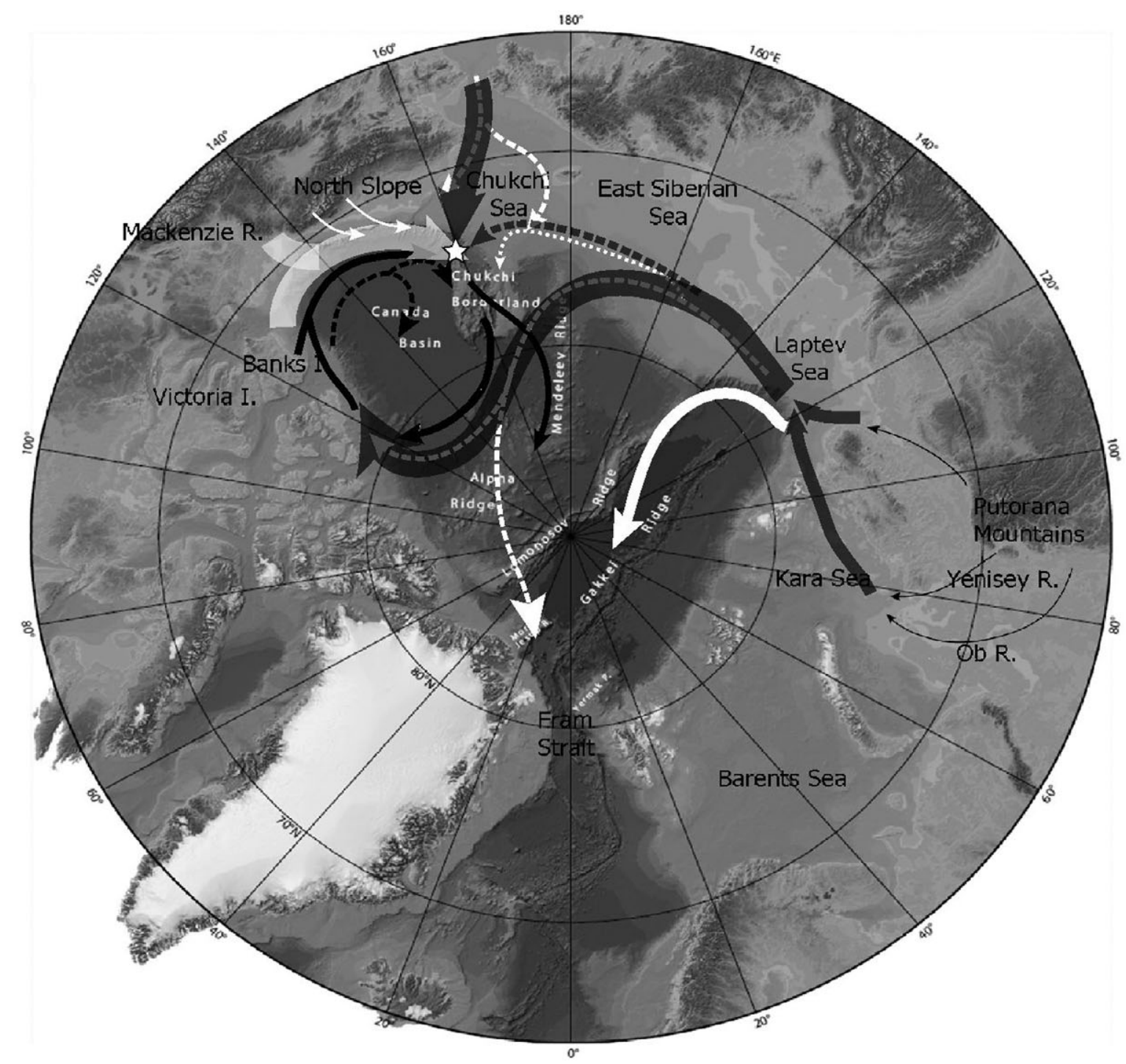

Bathymetric and topographic tints

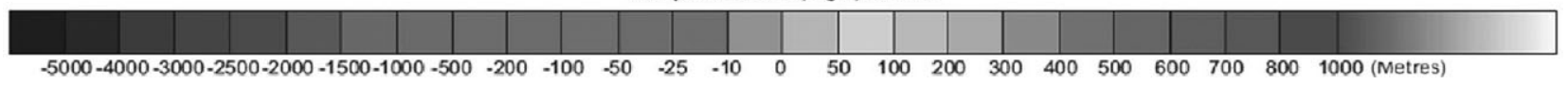

Fig. 10 Arctic Ocean bathymetric map with extreme states of the Arctic Oscillation (from Darby \& Bischof 2004), and interpretation of potential sources and transport of P25 sediments. Modern locations of the Transpolar Drift (TPD) and Beaufort Gyre (BG) are indicated (Fig. 1). The approximate location of P25 is indicated by the white star. Solid arrows indicate surface circulation during a negative phase of the Arctic Oscillation (AO-), and dashed arrows indicate surface circulation during its positive phase (AO+). The white dotted arrow indicates a possible circulation of TPD during very positive AO+. White, semi-transparent block arrows indicate interpreted transport pathways of the illite + goethite assemblage from the shelf off Banks Island and the Mackenzie River. Glauconite may also be derived from these regions. Note that these arrows follow the AO- circulation. Dark semi-transparent block arrows indicate interpreted transport pathways of the smectite + chlorite assemblage from the Putorana Mountains and Siberian Platform to the Kara and Laptev seas, and from sources in eastern Siberia and the Bering Sea through the Bering Strait to the Chukchi Sea. Note that these arrows follow the AO+ circulation. The dark semi-transparent dashed arrow indicates possible direct transport to the core site from a vastly shifted TPD during very positive AO+. Thin white arrows indicate a possible source and transport of glauconite from northern Alaska. (International Bathymetric Chart of the Arctic Ocean base map provided by Jakobsson, Macnab et al. 2008.)

dumped sediment into the Arctic Ocean and sea level rise re-established its connection with the Pacific. This allowed Pacific and Siberian sediment sources to again provide smectite and chlorite clay to the marginal seas, where it could potentially be transported to the Northwind Ridge (Darby et al. 2001). If transport occurred via sea ice, the prevailing surface circulation would dominate its dispersion. 
The modern circulation of wind-driven surface currents in the Arctic is directly affected by atmospheric pressure gradients, particularly by the AO, which is the leading mode of sea level pressure variability in the Northern Hemisphere, and which generally operates on monthly to decadal time scales (Thompson \& Wallace 1998; Rigor et al. 2002; Darby et al. 2006). Shifts in the mode of the AO thus influence the patterns of ice movement, as well as the degree and thickness of sea-ice coverage (Polyakov \& Johnson 2000; Kwok 2000; Rigor et al. 2002; Polyakov et al. 2003; Serreze et al. 2003; Zhang et al. 2003; Shimada et al. 2006, Darby \& Bischof, 2004; Steele et al. 2008). Numerous studies have indicated that a shift in the AO from its negative phase (AO-) to its positive phase $(\mathrm{AO}+)$ is associated with the thinning of sea ice in the BG, increased export of thick multiyear ice (largely from the Beaufort Sea) through the Fram Strait, and increased sea surface temperature (e.g., Rigor et al. 2002; Zhang et al. 2003; Pfirman et al. 2004; Steele et al. 2008).

Changes similar to those associated with shifts in the $\mathrm{AO}$, if they existed on millennial to glacial-interglacial time scales, could, in part, explain the variations in sedimentation patterns observed in P25. During AO-, the clockwise-rotating BG is relatively strengthened, and the counter-clockwise TPD is positioned closer to the Kara and Barents Sea, transporting ice directly out through the Fram Strait, and limiting its influence on sedimentation at the Northwind Ridge. At these times, sediment source regions for the Northwind Ridge are dominantly northwestern Canada, particularly the shelf off Banks Island, and the Mackenzie River (Darby \& Bischof 2004; Darby et al. 2006) (Fig. 10). Sediment-laden ice is transported directly over the core site from these sources by the circulating BG, although thick ice packs may have slowed the ice drift. This is consistent with the illite + goethite and glauconite assemblages that dominate glacial and deglacial periods in P25 (Fig. 10).

As the AO shifts to a positive vorticity, the TPD moves closer to North America, allowing the BG to capture ice floes originating from Siberian seas, and circulate them to the Amerasia Basin and the Northwind Ridge (Mysak 2001; Darby 2003; Hakkinen \& Proshutinsky 2004; Darby \& Bischof 2004; Darby et al. 2006) (Fig. 10). During especially positive phases of the AO, the TPD may even shift so far towards North America as to transport ice directly over the Northwind Ridge (Darby \& Bischof 2004) (Fig. 10). The TPD only shifts this far to the east during a very positive phase of the AO (above +2) (Kwok 2000; Rigor et al. 2002; Darby \& Bischof 2004).

Additionally, it is thought that during $\mathrm{AO}+$, increased export of ice from the BG into the North Atlantic possibly enhances the influx of ice drift through the Bering Strait into the Chukchi Sea (Rigor et al. 2002; Darby \& Bischof 2004; Pfirman et al. 2004) (Fig. 10), which could potentially raft smectite- and especially chlorite-rich sediment into the southern Canada Basin during high sea level stands (Fig. 10). Because a strongly positive AO can deliver both Siberian Sea and Bering Strait (southwestern Alaska) smectite to the Canada Basin, this process is consistent with the smectite + chlorite assemblage that dominates interglacial periods in the core (Fig. 10).

Thus, it is possible that the general circulation regimes associated with the negative and positive phases of the $\mathrm{AO}$ are also manifested on stadial and interstadial, and potentially glacial and interglacial, timescales, respectively. A more negative AO-like circulation might dominate stadials and glacials, whereas a more positive AO-like circulation may dominate interstadials and interglacials. Whether these general patterns of circulation are caused by atmospheric changes associated with shifts in the AO itself remains to be seen.

There is some evidence that the AO and AO-like atmospheric pressure variations operate on multiple time scales (Wang \& Ikeda 2000; Mysak 2001; Polyakov et al. 2003; Deser $\&$ Teng 2008). The AO has a seasonal pattern as well as an annual to decadal pattern (Thompson $\delta$ Wallace 1998; Thompson \& Wallace 2000a, b; Polyakov et al. 1999; Wang \& Ikeda 2000; Rigor et al. 2002; Deser $\delta$ Teng 2008). A longer, multi-decadal pattern (shifting every 50-80 years) has been termed the "low-frequency oscillation" or LFO (Polyakov et al. 2003). Finally, an AO-like circulation pattern operating on centennial to millennial timescales has been suggested by an analysis of the Holocene alkenone-derived proxy sea surface temperature records from the North Pacific and North Atlantic, corroborated with millennial-scale model simulations from a coupled atmosphere-ocean global circulation model (Kim et al. 2004). Although it is still uncertain whether an AO-like oscillation pattern exists on millennial or longer time scales, ice-rafted Fe grains from the Laptev Sea are found to vary in cores off Alaska with a millennial beat (Darby $\&$ Bischof 2004; Herman et al. 2006).

The drastically different atmospheric and climatic conditions associated with glacial and interglacial periods offer the potential to set up two different modes of atmospheric pressure and wind patterns, and, thus, sea-ice circulation. Modelling studies show that during the Last Glacial Maximum, atmospheric pressure gradients and geostrophic wind patterns were dramatically altered by the existence of the North American and Eurasian ice sheets (Nørgaard-Pedersen et al. 2003, and references therein). Model simulations also indicate that the Icelandic low was either weakened or displaced to the south- 
east, relative to its modern position, and that the Aleutian low was strengthened (Toracinta et al. 2002; Byrkjedal et al. 2006). In general, sea-level pressure increased over the Arctic during the Last Glacial Maximum (Byrkjedal et al. 2006). This is consistent with the dominant atmospheric conditions during the negative phase of the AO. $\mathrm{AO}-$ is associated with a high sea level pressure anomaly over the Arctic (Polyakov \& Johnson 2000; Rigor et al. 2002), as is the negative phase of the North Atlantic Oscillation (NAO), which is generally thought to be a regional representation of the AO (Mysak 2001). The negative AO/NAO indices are also associated with a weaker Icelandic low (Kwok 2000; Polyakov \& Johnson 2000; Mysak 2001). This imparts a dominantly anticyclonic circulation on the Arctic, strengthening the BG and constraining the TPD towards the eastern Arctic (Proshutinsky \& Johnson 1997; Rigor et al. 2002).

In contrast, modern conditions exhibit decreased high pressure over the Arctic, a stronger Icelandic low and a weaker Aleutian low, relative to the Last Glacial Maximum model studies (Toracinta et al. 2002; Byrkjedal et al. 2006). This is consistent with atmospheric conditions during the positive phase of the AO. That is, an increase in the $\mathrm{AO} / \mathrm{NAO}$ index corresponds to a weakening of the Aleutian low (Ambaum et al. 2001), an intensification of the Icelandic low (Kwok \& Rothrock 1999; Kwok 2000; Polyakov \& Johnson 2000) and a general decrease in Arctic high pressure (Polyakov \& Johnson 2000; Rigor et al. 2002). This sets up the dominantly cyclonic circulation in the Arctic, which creates a weaker BG and a TPD that is shifted closer to North America (Proshutinsky \& Johnson 1997; Kwok 2000; Rigor et al. 2002). Consequently, if during glacial periods atmospheric conditions are similar to those predicted by the Last Glacial Maximum models, they might create negative AO-like conditions, tending to promote anticyclonic circulation in the Arctic. Similarly, interglacial periods might have atmospheric conditions that promote cyclonic circulation, causing a tendency for the TPD to shift towards North America more often, or for longer periods of time. The sediment provenance and transport pathways presumably associated with these circulation patterns are consistent with the cyclic sedimentation regimes observed in our data for glacial-interglacial periods.

\section{Conclusions}

The variations in clay mineralogy in core P25 from the Northwind Ridge have demonstrated alternating sediment provenance depending on glacial-interglacial cycles. It is inferred that the predominant clay minerals during interglacial intervals, smectite and chlorite, are transported to the core site by currents and/or sea ice from northern Siberia, and from the Bering Sea. During glacial intervals, the predominant deposition of illite and goethite is presumably related to sediment discharged from the Laurentide Ice Sheet. A relatively strong BG circulation might have enhanced the transportation of this sediment to the P25 site, although the process may have been slowed by thick ice conditions. The glauconite variability is possibly associated with sediments from the North Slope of Alaska during deglacial events or with dolomite-rich sediments, which are characteristic of Laurentide iceberg-discharge pulses.

Factors such as terrestrial ice sheets, sea-ice extent and sea level have a great impact on glacial-interglacial sedimentation, and are likely the primary reasons for the observed sedimentation patterns in P25. Also, these sediment cycles, as well as modelling studies, are consistent with the hypothesis of a glacial-interglacial atmospheric variability that sets up alternating sea surface circulation patterns-similar to how the AO operates on shorter time scales today. With similar studies of other cores, it may become possible to piece together a confident understanding of the shifting sedimentation and circulation patterns, and their forcing, on these time scales.

\section{Acknowledgements}

We thank the Captain and Crew of the icebreaker USCGC Healy. We thank M. Torresan of the US Geological Survey, Menlo Park, CA, USA, for assisting with our access to the P25 core. This study was supported by funds from the US National Science Foundation's Office of Polar Programs (grants ARC-0612384 to JDO; ARC-0612473 to LP; and ARC-0612493 and ODP-0525881 to DAD), and by grants from the Kent State University Research Council to JDO. Renee Crane and Bethany Lavins assisted with sample preparation. This manuscript is based on LNY's Senior Honors Thesis while she was at the Department of Geology, Kent State University. We would also like to thank the Kent State University Honors College and the Senior Honors Thesis sponsors of LNY, Hugh and Jean Stewart and Barbara Dickerson, for their support in conjunction with this project. Two anonymous reviewers provided useful comments and suggestions that helped to improve the manuscript.

\section{References}

Aagaard K. 1984. The Beaufort undercurrent. In P.W. Barnes et al. (eds.): The Alaskan Beaufort Sea: ecosystems and environments. Pp. 47-71. New York: Academic Press.

Aagaard K., Swift J.H. \& Carmack E.C. 1985. Thermohaline circulation in the Arctic Mediterranean seas. Journal of Geophysical Research-Oceans 90, 4833-4846. 
Adler R., Polyak L., Ortiz J., Kaufman D., Channell J.E.T., Xuan C., Fornaciari E., Grottoli A. \& Sellen E. 2009. Sediment record from the western Arctic Ocean with an improved Late Quaternary age resolution: HOTRAX core HLY0503-8JPC, Mendeleev Ridge. Global and Planetary Change 68, 18-29.

Ambaum M.H.P., Hoskins B.J. \& Stephenson D.B. 2001. Arctic Oscillation or North Atlantic Oscillation? Journal of Climate 14, 3495-3507.

Arctic Summer West Scientific Party 1993. Cruise to the Chukchi Borderland, Arctic Ocean. EOS, Transactions of the American Geophysical Union 74, 253-254.

Balsam W.L. \& Deaton B.C. 1991. Sediment dispersal in the Atlantic Ocean: evaluation by visible light spectra. Reviews in Aquatic Sciences 4, 411-447.

Bigg G.R. \& Wadley M.R. 2001. The origin and flux of icebergs released into the last glacial maximum Northern Hemisphere oceans: the impact of ice sheet topography. Journal of Quaternary Science 16, 565-573.

Bischof J., Clark D. \& Vincent J. 1996. Pleistocene palaeoceanography of the central Arctic Ocean: the sources of ice rafted debris and the compressed sedimentary record. Palaeoceanography 11, 743-756.

Bischof J.A. \& Darby D.A. 1997. Mid to Late Pleistocene ice drift in the western Arctic Ocean: evidence for a different circulation in the past. Science 277, 74-78.

Bradley R.S. \& England J.H. 2008. The Younger Dryas and the sea of ancient ice. Quaternary Research 70, 1-10.

Byrkjedal O., Kvamsto N.G., Meland M. \& Jansen E. 2006. Sensitivity of last glacial maximum climate to sea ice conditions in the Nordic seas. Climate Dynamics 26, 473-487.

Campbell J.S. \& Clark D.L. 1977. Pleistocene turbidites of the Canada Abyssal Plain of the Arctic Ocean. Journal of Sedimentary Petrology 47, 657-670.

Clark D.L., Whitman R.R., Morgan K.A. \& Mackay S.D. 1980. Stratigraphy and glacio marine sediments of the Amerasian Basin, central Arctic Ocean. Geological Society of America Special Paper 181. Boulder, CO: Geological Society of America.

Clark R.N., Swayze G.A., Wise R., Livo K.E., Hoefen T.M., Kokaly R.F. \& Sutley S.J. 2003. USGS Digital Spectral Library splib05a. USGS Open-File Report 03-395. Denver, CO: US Geological Survey.

Colony R. \& Thorndike A.S. 1984. An estimate of the mean field of Arctic sea ice motion. Journal of Geophysical Research-Oceans 89, 10 623-10629.

Comiso J.C., Parkinson C.L., Gersten R. \& Stock L. 2008. Accelerated decline in the Arctic sea ice cover. Geophysical Research Letters 35, L01703, doi: 10.1029/2007GL031972.

Curry R. \& Mauritzen C. 2005. Dilution of the northern North Atlantic Ocean in recent decades. Science 308, 1772-1774.

Dalrymple R.W. \& Maass O.C. 1987. Clay mineralogy of late Cenozoic sediments in the CESAR cores, Alpha Ridge, central Arctic Ocean. Canadian Journal of Earth Sciences 24, 1562-1569.
Darby D.A. 1975. Kaolinite and other clay minerals in Arctic Ocean sediments. Journal of Sedimentary Petrology 45, 272-279.

Darby D.A. 2003. Sources of sediment found in sea ice from the western Arctic Ocean, new insights into processes of entrainment and drift patterns. Journal of Geophysical Research-Oceans 108, 3275.

Darby D.A. \& Bischof J.F. 2004. A Holocene record of changing Arctic Ocean ice drift analogous to the effects of the Arctic Oscillation. Palaeoceanography 19(1), article no. PA1027.

Darby D., Bischof J., Cutter G., de Vernal A., Hillaire-Marcel C., Dwyer G., McManus J., Osterman L., Polyak L. \& Poore R. 2001. New record of pronounced changes in Arctic Ocean circulation and climate. EOS, Transactions of the American Geophysical Union 82, 603-607.

Darby D.A., Bischof J., Spielhagen R., Marshall S. \& Herman S. 2002. Arctic ice export events and their potential impact on global climate during the late Pleistocene. Paleoceanography 17(2), 15.1-15.17.

Darby D.A., Naidu A.S., Mowatt T.C. \& Jones G. 1989. Sediment composition and sedimentary processes in the Arctic Ocean. In Y. Herman (ed.): The Arctic seasclimatology, oceanography, geology, and biology. Pp. 657-720. New York: Van Nostrand Reinhold.

Darby D.A., Polyak L. \& Bauch H. 2006. Past glacial and interglacial conditions in the Arctic Ocean and marginal seas-a review. Progress in Oceanography 71, 129-144.

Darby D.A. \& Zimmerman P. 2008. Ice-rafted detritus events in the Arctic during the last glacial interval and the timing of the Innuitian and Laurentide Ice Sheet calving events. Polar Research 27, 114-127.

Davis J.C. 1986. Statistics and data analysis in geology. 2nd edn. New York: John Wiley \& Sons.

Deconinck J.-F., Gillot P.-Y., Steinberg M. \& Strasser A. 2001. Syn-depositional, low temperature illite formation at the Jurassic-Cretaceous boundary (Purbeckian) in the Jura Mountains (Switzerland and France); K/Ar and delta ${ }^{18} \mathrm{O}$ evidence. Bulletin de la Societe Geologique de France 172, 343-348.

Deser C. \& Teng H. 2008. Evolution of Arctic sea ice concentration trends and the role of atmospheric circulation forcing, 1979-2007. Geophysical Research Letters 35, L02504, doi: 10.1029/2007GL032023.

Dethleff D., Rachold V., Tintelnot M. \& Antonow M. 2000. Sea-ice transport of riverine particles from the Laptev Sea to Fram Strait based on clay mineral studies. International Journal of Earth Sciences 89, 496-502.

Grim R.E. 1968. Clay mineralogy. 2nd edn. New York: McGraw Hill.

Herman S., Darby D.A., Cook M.S. \& Keigwin L.D. 2006. The century-scale history of the Arctic Oscillation based on detrital Fe grain provenance of Russian sea ice origins in the Arctic off Alaska. EOS, Transactions of the American Geophysical Union 87, Fall Meeting Supplement, abstract OS52B-06 MCS 310. 
Hakkinen S. \& Proshutinsky A. 2004. Freshwater content variability in the Arctic Ocean. Journal of Geophysical Research-Oceans 109, C03051, doi: 10.1029/ 2003JC001940.

Han L. 2005. Estimating chlorophyll-a concentration using first-derivative spectra in coastal water. International Journal of Remote Sensing 26, 5235-5244.

Hill D.E. \& Tedrow J.C.F. 1961. Weathering and soil formation in the Arctic environment. American Journal of Science 259, 84-101.

Hölemann J.A., Schirmacher M., Kassens H. \& Prange A. 1999. Geochemistry of surficial and ice-rafted sediments from the Laptev Sea (Siberia). Estuarine, Coastal Shelf Science $49,45-59$.

Holland M.M., Bitz C.M., Eby M. \& Weaver A.J. 2001. The role of ice-ocean interactions in the variability of the North Atlantic thermohaline circulation. Journal of Climate 14, 656-675.

Hunkins K., Thorndike E.M. \& Mathieu G. 1969. Nepheloid layers and bottom currents in the Arctic Ocean. Journal of Geophysical Research 74, 6995-7008.

Jakobsson M., Gardner J.V., Vogt P., Mayer L.A., Armstrong A., Backman J., Brennan R., Calder B., Hall J.K. \& Kraft B. 2005. Multibeam bathymetric and sediment profiler evidence for ice grounding on the Chukchi Borderland, Arctic Ocean. Quaternary Research 63, 150-160.

Jakobsson M., Lovlie R., Al-Hanbali H., Arnold E., Backman J. \& Morth M. 2000. Manganese color cycles in Arctic Ocean sediments constrain Pleistocene chronology. Geology $28,23-26$.

Jakobsson M., Macnab R., Mayer L., Anderson R., Edwards M., Hatzky J., Schenke H.-W. \& Johnson P. 2008. An improved bathymetric portrayal of the Arctic Ocean: implications for ocean modeling and geological, geophysical and oceanographic analyses. Geophysical Research Letters 35, L07602, doi: 10.1029/2008GL033520.

Jakobsson M., Polyak L., Edwards M.H., Kleman J. \& Coakley B.J. 2008. Glacial geomorphology of the central Arctic Ocean: Chukchi Borderland and the Lomonosov Ridge. Earth Surface Processes and Landforms 33, 526-545.

Jones E.P. 2001. Circulation in the Arctic Ocean. Polar Research 20, 139-146.

Kalinenko V.V. 2001. Clay minerals in sediments of the Arctic seas. Lithology and Mineral Resources 36, 362-372.

Kim J.-H., Rimbu N., Lorenz S.J., Lohmann G., Nam S.-I., Schouten S., Rühlemann C. \& Schneider R.R. 2004. North Pacific and North Atlantic sea-surface temperature variability during the Holocene. Quaternary Science Reviews 23, 2141-2154.

Knies J. \& Vogt C. 2003. Freshwater pulses in the eastern Arctic Ocean during Saalian and Early Weichselian ice-sheet collapse. Quaternary Research 60, 243-251.

Kwok R. 2000. Recent changes in Arctic Ocean sea lee motion associated with the North Atlantic Oscillation. Geophysical Research Letters 27, 775-778.
Kwok R. \& Rothrock D.A. 1999. Variability of Fram Strait ice flux and North Atlantic Oscillation. Journal of Geophysical Research-Oceans 104, 5177-5189.

Löwemark L., Jakobsson M., Mörth M. \& Backman J. 2008. Arctic Ocean manganese contents and sediment colour cycles. Polar Research 27, 105-113.

Macquaker J.H.S., Keller M.A. \& Taylor K.G. 1999. Sequence stratigraphic analysis of the lower part of the pebble shale unit, Canning River, northeastern Alaska. In ANWR Assessment Team: The oil and gas resource potential of the 1002 Area, Arctic National Wildife Refuge, Alaska. USGS Open-File Report 98-34. Pp. SS1-SS15. Denver, CO: US Geological Survey.

Mangerud J., Jakobsson M., Alexanderson H., Astakhov V., Clarke G.K.C., Henriksen M., Hjort C., Krinner G., Lunkka J., Moller P., Murray A., Nikolskaya O., Saarnisto M. \& Svendsen J.I. 2004. Ice-dammed lakes and rerouting of the drainage of northern Eurasia during the last glaciation. Quaternary Science Reviews 23, 1313-1332.

Martinson D.G., Pisias N.G., Hays J.D., Imbrie J., Moore T.C. Jr. \& Shackleton N.J. 1987. Age dating and the orbital theory of the ice ages: development of a high-resolution 0 to 300,000-year chronostratigraphy. Quaternary Research 27, $1-29$.

McCave I.N., Kiefer T., Thornalley D.J.R. \& Elderfield H. 2005. Deep flow in the Madagascar-Mascarene Basin over the last 150000 years. Philosophical Transactions of the Royal Society A 363, 81-99.

McManus D.A., Kelley J.C. \& Creager J.S. 1969. Continental shelf sedimentation in an Arctic environment. Geological Society of America Bulletin 80, 1961-1984.

Moore D.M. \& Reynolds R.C. 1997. X-ray diffraction and the identification and analysis of clay minerals. Oxford: Oxford University Press.

Mørup S., Saksager O., Madsen M.B., Bentzon M.D. \& Koch C.J.W. 1990. Weathering of basalt in an Arctic climate. Hyperfine Interactions 57, 2269-2273.

Mysak L. 2001. Patterns of Arctic circulation. Science 293, 1269-1270.

Naidu A.S., Burrell D.C. \& Hood D.W. 1971. Clay mineral composition and geologic significance of some Beaufort Sea sediments. Journal of Sedimentary Petrology 41, 691-694.

Naidu A.S. \& Mowatt T.C. 1983. Sources and dispersal patterns of clay minerals in surface sediments from the continental shelf areas off Alaska. Geological Society of America Bulletin 94, 841-854.

Nørgaard-Pedersen N., Mikkelsen N. \& Kristoffersen Y. 2007. Arctic Ocean record of last two glacial-interglacial cycles off North Greenland/Ellesmere Island-implications for glacial history. Marine Geology 244, 93-108.

Nørgaard-Pedersen N., Spielhagen R.F., Erlenkeuser H., Grootes P.M., Heinemeier J. \& Knies J. 2003. Arctic Ocean during the Last Glacial Maximum: Atlantic and polar domains of surface watermass distribution and ice cover. Palaeoceanography 18, 1063.

Ortiz J., Polyak L., Adler R., Jakobsson M. \& Darby D. 2007. Late Pleistocene sediment provenance on the Mendeleev 
Ridge, Arctic Ocean, from XRF elemental analysis and diffuse spectral reflectance measurements. EOS, Transactions of the American Geophysical Union 88, Fall Meeting Supplement, abstract PP51A-0184.

Ortiz J.D., Polyak L., Grebmeier J.M., Darby D., Eberl D.D., Naidu S. \& Nof D. 2009. Provenance of Holocene sediment on the Chukchi-Alaskan margin based on combined diffuse spectral reflectance and quantitative X-ray diffraction analysis. Global and Planetary Change 68, 73-84.

Ortiz J.D., Polyak L., Jakobsson M. \& Darby D. 2006. Quaternary Inferences on central Arctic Ocean circulation and sediment provenance based on diffuse spectral reflectance analysis. EOS, Transactions of the American Geophysical Union 87, Fall Meeting Supplement, abstract OS53B-1098.

Parrish J.T., Droser M.L. \& Bottjer D.J. 2001. A Triassic upwelling zone: the Shublik Formation, Arctic Alaska, U.S.A. Journal of Sedimentary Research 71, 272-285.

Petschick R., Kuhn G. \& Gingele F. 1996. Clay mineral distribution in surface sediments of the South Atlantic: sources, transport, and relation to oceanography. Marine Geology 130, 203-229.

Pfirman S., Haxby W.F., Colony R. \& Rigor I. 2004. Variability in Arctic sea ice drift. Geophysical Research Letters 31, L16402, doi: 10.1029/2004GL020063.

Phillips R. \& Grantz A. 1997. Quaternary history of sea ice and palaeoclimate in the Amerasia basin, Arctic Ocean, as recorded in the cyclical strata of Northwind Ridge. Geological Society of America Bulletin 109, 1101-1115.

Phillips R.L. \& Grantz A. 2001. Regional variations in the provenance and abundance of ice-rafted clasts in Arctic Ocean sediments: implications for the configuration of late Quaternary oceanic and atmospheric circulation in the Arctic. Marine Geology 172, 91-115.

Pickart R.S. 2004. Shelfbreak circulation in the Alaskan Beaufort Sea: mean structure and variability. Journal of Geophysical Research-Oceans 109, C04024, doi: 10.1029/ 2003JC001912.

Polyak L., Bischof J., Ortiz J., Darby D.A., Channell J., Xuan C., Kaufman D., Lovlie R., Schneider D. \& Adler R. 2009. Late Quaternary stratigraphy and sedimentation patterns in the western Arctic Ocean. Global and Planetary Change 68, 4-17.

Polyak L., Curry W.B., Darby D.A., Bischof J. \& Cronin T.M. 2004. Contrasting glacial/interglacial regimes in the western Arctic Ocean as exemplified by a sedimentary record from the Mendeleev Ridge. Palaeogeography, Palaeoclimatology, Palaeoecology 203, 73-93.

Polyak L., Darby D.A., Bischof J. \& Jakobsson M. 2007. Stratigraphic constraints on late Pleistocene glacial erosion and deglaciation of the Chukchi margin, Arctic Ocean. Quaternary Research 67, 234-245.

Polyak L., Edwards M.H., Coakley B.J. \& Jakobsson M. 2001. Ice shelves in the Pleistocene Arctic Ocean inferred from glaciogenic deep-sea bedforms. Nature 410, 453-457.

Polyak L., Niessen F., Gataullin V. \& Gainanov V. 2008. The eastern extent of the Barents-Kara ice sheet during the
Last Glacial Maximum based on seismic-reflection data from the eastern Kara Sea. Polar Research 27, 162-174.

Polyakov I.V., Bekryaev R.V., Alekseev G.V., Bhatt U.S., Colony R.L., Johnson M.A., Maskshtas A.P. \& Walsh D. 2003. Variability and trends of air temperature and pressure in the maritime Arctic, 1875-2000. Journal of Climate 16, 2067-2077.

Polyakov I.V. \& Johnson M.A. 2000. Arctic decadal and interdecadal variability. Geophysical Research Letters 27, 4097-4100.

Polyakov I.V., Proshutinsky A.Y. \& Johnson M.A. 1999. Seasonal cycles in two regimes of Arctic climate. Journal of Geophysical Research-Oceans 104, 25 761-25 788.

Poore R., Osterman L., Curry W. \& Phillips R. 1999. Late Pleistocene and Holocene meltwater events in the western Arctic Ocean. Geology 27, 759-762.

Press W.H., Teukolsky S.A., Vetterling W.T. \& Flannery B.P. 1992. Numerical recipes in Fortran 77: the art of scientific computing. 2nd edn. Cambridge: Cambridge University Press.

Proshutinsky A.Y. \& Johnson M.A. 1997. Two circulation regimes of the wind-driven Arctic Ocean. Journal of Geophysical Research-Oceans 102, 12 493-12 514.

Reimnitz E., McCormick M., McDougall K. \& Brouwers E. 1993. Sediment export by ice rafting from a coastal polynya, Arctic Alaska, U.S.A. Arctic and Alpine Research 25, 83-98.

Rigor I.G., Wallace J.M. \& Colony R.L. 2002. Response of sea ice to the Arctic Oscillation. Journal of Climate 15, 2648-2663.

Rodeick C. 1979. The origin, distribution, and depositional history of gravel deposits on the Beaufort Sea continental shelf, Alaska. USGS Open-File Report 79-234. Denver, CO: US Geological Survey.

Rudels B., Jones E.P., Anderson L.G. \& Kattner G. 1994. On the intermediate depth waters of the Arctic Ocean. In O.M. Johannessen et al. (eds.): The polar oceans and their role in shaping the global environment. Pp. 33-46.

Washington, D.C.: American Geophysical Union.

Rudels B., Jones E.P., Schauer U. \& Eriksson P. 2004. Atlantic sources of the Arctic Ocean surface and halocline waters. Polar Research 23, 181-208.

Serreze M.C., Maslanik J.A., Scambos T.A., Fetterer F., Stroeve J., Knowles K., Fowler C., Drobot S., Barry R.G. \& Haran T.M. 2003. A record minimum Arctic sea ice extent and area in 2002. Geophysical Research Letters 30, article no. 1110, doi: 10.1029/2002GL016406.

Shimada K., Kamoshida T., Itoh M., Nishino S., Carmack E., McLaughlin F., Zimmermann S. \& Proshutinsky A. 2006. Pacific Ocean inflow: influence on catastrophic reduction of sea ice cover in the Arctic Ocean. Geophysical Research Letters 33, L08605, doi: 10.1029/2005GL025624.

Steele M., Ermold W. \& Zhang J. 2008. Arctic Ocean surface warming trends over the past 100 years. Geophysical Research Letters 35, L02614, doi: 10.1029/2007GL031651.

Stein R. 2008. Arctic Ocean sediments: processes, proxies, and paleoenvironment. Oxford: Elsevier. 
Stein R., Dittmers K.H., Fahl K., Kraus M., Matthiessen J., Niessen F., Pirrung M., Polyakova Y.I., Schoster F., Steinke T. \& Fütterer D.K. 2004. Arctic (palaeo) river discharge and environmental change: evidence from the Holocene Kara Sea sedimentary record. Quaternary Science Reviews 23, 1485-1511.

Svendsen J.I., Alexanderson H., Astakhob V.I., Demidov I., Dowdeswell J.A., Funder S., Gataullin V., Henriksen M., Hjort C., Houmark-Nielsen M., Hubberten H.W., Ingolfsson O., Jakobsson M., Kjaer K.H., Larsen E., Lokrantz H., Lunkka J.P., Lysa A., Mangerud J., Matiouchkov A., Murray A., Moller P., Niessen F., Nikolskaya O., Polyak L. Saarnisto M., Siegert C., Siegert M., Spielhagen R.F. \& Stein R. 2004. Late Quaternary ice sheet history of northern Eurasia. Quaternary Science Reviews 23, 1229-1271.

Thompson D.W.J. \& Wallace J.M. 1998. The Arctic Oscillation signature in the wintertime geopotential height and temperature fields. Geophysical Research Letters 25, 1297-1300.

Thompson D.W.J. \& Wallace J.M. 2000a. Annular modes in the extratropical circulation. Part I: month-to-month variability. Journal of Climate 13, 1000-1016.

Thompson D.W.J. \& Wallace J.M. 2000b. Annular modes in the extratropical circulation. Part II: trends. Journal of Climate 13, 1018-1036.

Toracinta E.R., Bromwich D.H. \& Wei H. 2002. High resolution LGM simulations over the Laurentide Ice Sheet using Polar MM5. Paper presented at the Twelfth PSU/ NCAR Mesoscale Model Users' Workshop, 24-25 June, Boulder, CO, USA.

van der Zee C., Roberts D.R., Rancourt D.G. \& Slomp C.P. 2003. Nanogoethite is the dominant reactive oxyhydroxide phase in lake and marine sediments. Geology 31, 993-996.

Viscosi-Shirley C., Mammone K., Pisias N. \& Dymond J. 2003. Clay mineralogy and multi-element chemistry of surface sediments on the Siberian-Arctic shelf: implications for sediment provenance and grain size sorting. Continental Shelf Research 23, 1175-1200.

Viscosi-Shirley C., Pisias N. \& Mammone K. 2003. Sediment source strength, transport pathways and accumulation patterns on the Siberian-Arctic's Chukchi and Laptev shelves. Continental Shelf Research 23, 1201-1225.

Vogt C. 1997. Regional and temporal variations of mineral assemblages in Arctic Ocean sediments as climatic indicator during glacial/interglacial changes. Reports on Polar Research 251. Bremerhaven: Alfred Wegener Institute for Polar and Marine Research.

Vogt C. 2009. Data report: semiquantitative determination of detrital input to ACEX sites based on bulk sample X-ray diffraction data. In J. Backman et al.: Proceedings of the
Integrated Ocean Drilling Program 302. Edinburgh: Integrated Ocean Drilling Program Management International.

Vogt C. \& Knies J. 2008. Sediment dynamics in the Eurasian Arctic Ocean during the last deglaciation-the clay mineral group smectite perspective. Marine Geology 250, 211-222.

Vogt C. \& Knies J. 2009. Sediment pathways in the western Barents Sea inferred from clay mineral assemblages in surface sediments. Norwegian Journal of Geology 89, 41-55.

Wahsner M., Müller C., Stein R., Ivanov G., Levitan M., Shelekhova E. \& Tarasov G. 1999. Clay-mineral distribution in surface sediments of the Eurasian Arctic Ocean and continental margin as indicator for source areas and transport pathways-a synthesis. Boreas 28, 215-233.

Wang J. \& Ikeda M. 2000. Arctic Oscillation and Arctic sea-ice oscillation. Geophysical Research Letters 27, 1287-1290.

Weingartner T.J., Aagaard K., Woodgate R., Danielson S., Sasaki Y. \& Cavalieri D. 2005. Circulation on the north central Chukchi Sea Shelf. Deep-Sea Research Part II 52, 3150-3174.

Williams W.J., Melling H., Carmack E.C. \& Ingram R.G. 2008. Kugmallit Valley as a conduit for cross-shelf exchange on the Mackenzie Shelf in the Beaufort Sea, Journal of Geophysical Research-Oceans 113, C02007, doi: 10.1029/2006JC003591.

Winkler A., Wolf-Welling T.C.W., Stattegger K. \& Thiede J. 2002. Clay mineral sedimentation in high northern latitude deep-sea basins since the Middle Miocene (ODP Leg 151, NAAG). International Journal of Earth Sciences 91, 133-148.

Winter B.L., Johnson C.M. \& Clark D.L. 1997. Strontium, neodymium, and lead isotope variations of authigenic and silicate sediment components from the Late Cenozoic Arctic Ocean: implications for sediment provenance and the source of trace metals in seawater. Geochimica et Cosmochimica Acta 61, 4181-4200.

Woodgate R.A., Aagaard K., Swift J.H., Falkner K.K. \& Smethie W.M. 2005. Pacific ventilation of the Arctic Ocean's lower halocline by upwelling and diapycnal mixing over the continental margin. Geophysical Research Letters 32, L18609, doi: 10.1029/2005GL023999.

Yacobi Y.Z. \& Gitelson A.A. 2000. Simultaneous remote measurement of chlorophyll and total seston in productive inland waters. Verhandlungen des Internationalen Verein Limnologie 27, 2983-2986.

Zhang X., Ikeda M. \& Walsh J.E. 2003. Arctic sea ice and freshwater changes driven by the atmospheric leading mode in a coupled sea ice-ocean model. Journal of Climate $16,2159-2177$. 